\title{
Openness and inflation volatility: Panel data evidence*
}

\author{
Christopher Bowdler ${ }^{*}$ \\ Nuffield College \\ University of Oxford \\ christopher.bowdler@nuf.ox.ac.uk
}

\author{
Adeel Malik \\ Centre for the Study of African Economies \\ University of Oxford \\ adeel.malik@economics.ox.ac.uk
}

\begin{abstract}
Trade openness can reduce inflation volatility through limiting recourse to seigniorage during periods of temporary fiscal deficits, and by shifting consumption and production towards goods for which the terms of trade are relatively stable. This paper provides evidence for a negative effect of openness on inflation volatility using a dynamic panel model that controls for the endogeneity of openness and the effects of both average inflation and the exchange rate regime. The relationship is found to be strongest amongst developing and emerging market economies. We show that openness reduces the volatility of reserve money growth and terms of trade growth and that these effects contribute to the relationship between openness and inflation volatility.
\end{abstract}

Keywords: Openness, inflation, volatility, globalisation, seigniorage.

JEL classification: E31, F41, O57.

\footnotetext{
${ }^{*}$ We thank Pierre-Richard Agenor, David Bevan, John Bluedorn, Stephen Bond, Vijay Joshi, Mans Soderbom and Francis Teal for helpful discussions on this topic, and seminar participants in Oxford, Manchester and the $20^{\text {th }}$ Annual Congress of the European Economic Association in Amsterdam for comments. We are especially grateful to Jon Temple for detailed suggestions that helped to improve the paper. All errors are the responsibility of the authors. Bowdler acknowledges financial support from a British Academy post-doctoral fellowship.

** Corresponding author. Address: Nuffield College, New Road, Oxford, OX1 1NF, UK. Phone: +44 1865 278 508. Fax: +44 1865278 621. Email: christopher.bowdler@nuf.ox.ac.uk.
} 


\section{Introduction}

A striking feature of recent global macroeconomic performance has been the substantial decline in inflation volatility. In the United States inflation volatility has fallen by two thirds since the mid-1980s and similar trends have been observed in other OECD countries (Blanchard and Simon 2001). Even developing countries, which continue to experience higher and more volatile inflation than the industrial countries, have seen inflation volatility fall since the early 1990s. The decline in inflation volatility comes at a time of increasing international trade. This paper asks whether or not inflation volatility is related to trade openness - can the greater inflation stability of the 1990s be described, in the parlance of Rogoff (2003), as a further 'unsung benefit of globalization'?

We propose two mechanisms through which openness may restrict inflation volatility. The first relates to the collection of seigniorage. If fluctuations in economic activity lead to regular changes in revenues from conventional sources of taxation governments may be forced to vary seigniorage to compensate, especially in developing countries in which there are limits to borrowing (Little et al. 1993). The extent to which governments choose to resolve transitory deficits through temporary changes in seigniorage, as opposed to changes in spending or other tax rates, will affect the volatility of the growth rate of the money supply and hence the volatility of inflation. The greater the welfare losses associated with inflation volatility the stronger the incentive for governments to pursue means other than seigniorage to compensate for fluctuations in the tax base. In open economies inflation volatility will be relatively costly if international trade induces stronger competition in markets supplied by domestic producers of tradables. This will increase the elasticity of the demand curve facing each firm and a given amount of inflation volatility will then translate into larger fluctuations in revenues, reducing welfare if firms are averse to sales risk. In order to avoid this welfare loss the government can use measures other than the inflation tax to deal with temporary reductions in revenues and this will reduce inflation volatility.

The second mechanism relates to the set of markets in which countries participate. If the structure of consumption and production shifts towards high value added products inflation volatility likely decreases because the terms of trade for such products are more stable (Bax- 
ter and Kouparitsas 2000). We argue that trade openness supports this transition. In terms of consumption trade contributes to the supply of high value added consumer goods, many of which are not produced in low income countries, whilst on the production side trade can support industrialisation through providing access to larger markets. To the extent that openness contributes to these forms of structural change the terms of trade will stabilise, and inflation volatility will decrease.

Preliminary evidence suggests that trade integration is indeed associated with inflation stability: Brahmbhatt and Dadush (1996) report that during the period 1984-93 inflation volatility in countries that were slow to integrate was twice that in countries that achieved rapid integration. ${ }^{1}$ Similarly, large reductions in inflation volatility are often observed after the dates identified by Wacziarg and Welch (2003) as marking the start of a liberal trade regime, e.g. the coefficient of variation for inflation during the five years before and after the liberalization date fell from 1.25 to 0.37 in the case of the Philippines and from 8.83 to 1.21 in the case of Cameroon (figures are based on our calculations). More recently, Lo et al. (2005) provide crosscountry regression evidence demonstrating a negative correlation between openness and inflation volatility. ${ }^{2}$ However, existing studies have not tried to separate correlation and causation when examining the evidence linking openness and inflation volatility, nor has the robustness of the relationship been investigated in any detail.

This paper provides a first systematic account of the openness-inflation volatility relationship. Using panel data spanning 96 countries and four decades we demonstrate a robust negative effect of openness on inflation volatility. Our work departs from previous research in that we move beyond cross-sectional correlations and utilise temporal variation in the data. More importantly, we address the potential endogeneity of openness by using lagged values of openness and population size as instruments in estimating a dynamic panel model.

The evidence that we present parallels the negative relationship between openness and av-

\footnotetext{
${ }^{1}$ Inflation standard deviations for slow and fast integrators were $13.27 \%$ and $7.24 \%$ respectively. The "speed of integration index" is based on four indicators: the ratio of trade to GDP, the ratio of foreign direct investment to GDP, institutional investors' credit ratings and the share of manufactures in exports.

${ }^{2}$ Two other studies, Bleaney and Fielding (2002) and Gruben and McLeod (2004), provide brief evidence on this topic.
} 
erage inflation documented in Romer (1993). ${ }^{3}$ However, we show that openness has a negative and statistically significant effect on inflation volatility even after controlling for mean inflation. We demonstrate the robustness of our findings to an unusually wide range of controls, including per capita income, country size, output volatility and the exchange rate regime. Furthermore, our results are not affected by cross-country differences in financial development, indebtedness, political constraints, the adoption of inflation targeting and participation in IMF structural adjustment programmes. However, the relationship is shown to be stronger amongst developing and emerging market economies than amongst OECD countries.

In order to evaluate the proposed channels linking openness and inflation volatility we augment our basic regressions with measures of the volatility of money supply growth (which captures the importance of the seigniorage channel) and terms of trade growth (which proxies the effect of greater international price stability in markets for high value added products). This leads to a large reduction in the effect of openness, such that it is insignificant at conventional levels. Auxiliary regressions are then presented to show that trade openness is a negative predictor of monetary and terms of trade volatility. These findings are consistent with the hypothesis that openness reduces inflation volatility through first decreasing monetary and terms of trade volatility.

Understanding the determinants of inflation volatility is important. The remits of many central banks stipulate not only a target for inflation, but also the bands in which inflation should fluctuate, suggesting that policy-makers care about the level of inflation volatility. This may be due to a belief that inflation volatility influences broader macroeconomic performance, for example Elder (2004) and Byrne and Davis (2004) provide evidence that volatile inflation reduces investment and growth. In related work Buraschi and Jiltsov (2004) present a model in which inflation volatility increases the risk premium in asset markets. Our results are also of interest because they complement research into other forms of macroeconomic volatility. Recent evidence on the relationship between openness and output volatility is ambiguous, suggesting either a positive or a negative link depending on the sample coverage and the set of controls;

\footnotetext{
${ }^{3}$ The Romer evidence has been challenged, see for example Bleaney (1999) and Alfaro (2005), but in a recent contribution Gruben and McLeod (2004) report that greater openness is associated with lower mean inflation, especially during the 1990s.
} 
see for example Easterly et al. (2001) and Levy-Yeyati and Sturzenegger (2003). The results presented in this paper indicate that the relationship between openness and inflation volatility is more systematic, i.e. openness appears to exert a stronger effect on nominal volatility than on real volatility.

The remainder of this paper expands on these points and is organised as follows. Section 2 discusses potential channels linking openness and inflation volatility. Section 3 sets out the econometric approach and describes the data. Section 4 presents the empirical results and in Section 5 we interpret our findings in terms of the mechanisms discussed in Section 2. Finally, Section 6 concludes.

\section{Openness and inflation volatility}

In this section we trace out possible channels linking openness and inflation volatility. One view is that openness actually increases instability. For example, if trade is based around primary commodities, as has traditionally been the case in many developing countries, openness implies greater exposure to some of the most volatile international markets. Similarly, openness increases vulnerability to exchange rate fluctuations, although the importance of this will depend on the exchange rate regime. ${ }^{4}$

On the other hand, there are several channels through which openness may reduce inflation volatility. The first idea that we emphasise derives from a public finance interpretation of the inflation process. Consider a government that is solvent over the long-term but faces some variability in the revenues that it collects, e.g. due to business cycle fluctuations that affect the tax base. If there are some constraints on government borrowing, as is often the case in developing countries (see Little et al. 1993), periods of low revenues will require either fiscal contractions (reductions in spending or increases in tax rates) or temporary recourse to seigniorage (the inflation tax). The relevance of such a scenario is demonstrated by Aisen and Veiga (2005a) who find that during periods of negative GDP growth (and hence low tax revenues)

\footnotetext{
${ }^{4}$ There is also a literature on the consequences of greater financial openness, which can raise exposure to procyclical capital flows and therefore increase volatility (Aghion, Bacchetta and Banerjee 2004). We address this possibility in the discussion of our results in section 4 and also in our special appendix for referees.
} 
seigniorage requirements increase. ${ }^{5}$ The argument that we advance is that in these situations reliance on seigniorage is negatively related to openness. This implies that when the tax base is temporarily diminished, episodes in which seigniorage is increased to generate income and then reduced once revenues from conventional taxation have recovered can be avoided. As a result the variability of the growth rate of the monetary base, and hence the growth rate of the aggregate money supply, will decrease. Assuming that inflation partly depends on the rate of monetary expansion, inflation volatility will be lower in open economies (the monetary view of inflation has often been challenged but the empirical evidence indicates that it is relevant to developing countries, see Loungani and Swagel 2001).

A key question is why should openness deter seigniorage during periods in which other tax revenues are temporarily low? The explanation that we focus upon is that the costs of inflation and inflation volatility may be larger in more open economies, as argued by Temple (2002). For example, openness increases competition in markets supplied by domestic producers of tradables and this causes the demand curve facing each firm to become more price elastic, see Chen et al. (2004). A given amount of inflation volatility will then translate into larger fluctuations in sales and revenues and, assuming firms are averse to sales risk, inflation volatility will induce greater welfare loss. ${ }^{6}$ This may strengthen government commitment to stable inflation and as a result governments will rely on spending cuts or increases in direct tax rates during periods of fiscal stress, not seigniorage. ${ }^{7}$

Aisen and Veiga (2005a) show that a de jure measure of openness taken from the Index

\footnotetext{
${ }^{5}$ Catao and Terrones (2005) present a model in which fiscal deficits cause inflation via the seigniorage channel and provide evidence consistent with the model. Click (1998) and Aisen and Veiga (2005b) provide empirical evidence on the determinants of seigniorage and inflation respectively, and both studies are motivated from a public finance perspective.

${ }^{6}$ Razin (2005) develops a micro-founded model in which trade and financial openness increase society's aversion to unexpected inflation. To the extent that more volatile inflation implies greater variability in the unexpected component of inflation, inflation volatility will be more costly in open economies.

${ }^{7}$ An alternative reason for openness deterring temporary recourse to seigniorage is that over time the revenues obtained from taxing tradables are less volatile than those obtained from taxing non-tradables, e.g. because the former can be monitored and taxed as they pass through ports and are therefore less likely to be diverted to the black economy in the aftermath of shocks.
} 
of Economic Freedom (Gwartney and Lawson 2002) reduces the level of seigniorage. ${ }^{8}$ The argument that we present extends this relationship so that openness decreases the variance of seigniorage (and hence inflation) through creating incentives for credit constrained governments to pursue other ways of balancing budgets when revenues fluctuate, and in section 5 we present evidence consistent with this channel. Of course, in practice the means and variances of both seigniorage and inflation are highly correlated. In our empirical work we therefore take care to test the hypothesis that openness decreases inflation volatility after controlling for the important relationship between openness and mean inflation documented in Romer (1993). ${ }^{9}$

A second channel through which openness can affect inflation volatility is the structure of consumption. Increases in income levels likely induce a partial shift in consumer demand, away from low value added agricultural products and towards manufactured goods. The degree of substitution in consumption will depend on openness to trade because developing countries often lack capacity in the supply of certain consumer goods but can compensate by importing these goods in order to re-structure consumption in favour of high value added products. As terms of trade volatility for manufactured goods is one third less than aggregate terms of trade volatility (Baxter and Kouparitsas 2000) this change in the structure of consumption, achieved through the flexibility in supply provided by trade, will stabilise consumer price inflation. Hence, countries that open up more rapidly, be it due to improved market access or governments reducing tariffs and quotas, will experience larger reductions in inflation volatility.

An example of this mechanism taking effect occurred in South Africa following the removal of tariffs and other trade barriers at the start of the 1990s, a process linked to political reforms that occurred at the time. This caused the share of exports plus imports in GDP to rise, from $45 \%$ during the period $1991-95$ to $53.2 \%$ during the period $1996-2000$. Furthermore, most of this increase in trade was concentrated in the manufacturing sector. Aron and Muellbauer (2000) develop an econometric model for the share of imported manufactures in total domestic

\footnotetext{
${ }^{8}$ Similarly, Terra (1998) shows that average inflation in Latin American countries following the debt crisis period is negatively related to openness, and explains this finding in terms of debt repayment financed via seigniorage.

${ }^{9}$ The link between openness and the level of inflation has been challenged by Bleaney (1999) and Alfaro (2005), while Gruben and McLeod (2004) argue that the original Romer (1993) finding is robust, particularly during the 1990s.
} 
consumption of manufactures and find that the underlying trend in this quantity rose by $40 \%$ between 1991 and 1998, i.e. stronger trade links boosted the supply of high value added products for which domestic production capacity was limited. Against this background of increasing openness and greater foreign supply of manufactured goods the standard deviation of consumer price inflation fell from $3.04 \%$ for the period $1991-95$ to $2.16 \%$ for the period $1996-2000$ (figures are based on our calculation). Although this evidence does not demonstrate a causal link, it is consistent with the mechanism that we have described.

The link between openness and the structure of imports/consumption is related to the idea that trade serves as a risk-coping mechanism. In much of the developing world climatic shocks affect inflation volatility through their impact on food supply. Relatively open economies have been better able to reduce the sensitivity of food prices to climatic shocks by importing food during times of shortage, see Joshi and Little (1994) for an account of the Indian experience.

Openness may also restrict inflation volatility via export structures. Export prices are not included in the consumer price index directly but may exert an indirect effect via aggregate demand. In developing countries an export price boom, for example, typically increases government revenues, especially if major export industries are state owned, and these windfall gains are often used for wasteful public consumption that raises excess demand and inflation for some period (Lal and Myint 1996; Collier et al. 1999). A shift in exports from agriculture to manufacturing will stabilise the terms of trade because volatility is lower in high value added sectors. This is likely to reduce the volatility of government spending, which will in turn reduce inflation volatility.

A key question, then, is whether or not openness is associated with structural change in production, towards manufacturing. Breinlich (2005) presents a model in which a geographic predisposition to trade provides access to large markets and thereby supports industrialization through providing sufficient demand to absorb increased output of manufactures. Evidence reported by Breinlich supports the predictions of the model, as do the recent experiences of China and other East Asian countries in which trade has underpinned manufacturing growth. ${ }^{10}$

\footnotetext{
${ }^{10}$ Models of the industrialisation process are clearly most relevant to developing nations. In high income countries greater openness need not be associated with manufacturing growth. Indeed, international trade is sometimes blamed for de-industrialisation in OECD countries. This suggests that the link between openness
} 
In related work Hausmann and Gavin (1996) note that regional trade agreements in Latin America are associated with an increase in the share of manufactures in total exports, suggesting that trade supports expansion in high value added industries. Our own empirical analysis also supports a link running from trade to manufacturing growth. A log-linear panel regression of the manufacturing share in GDP on the once lagged trade share in GDP plus fixed effects and time dummies yields an elasticity of 0.16 and a $t$-ratio of 2.23 . If the model is extended to include the first lags of per capita income and a measure of real exchange rate over-valuation (cited by Dollar (1992) as a barrier to industrialisation) the openness elasticity increases to 0.17 and the corresponding t-ratio is $1.81 .{ }^{11}$ This suggests that openness Granger causes manufacturing growth and supports the view that openness reduces inflation volatility by shifting production to sectors that are more stable.

The hypothesis that openness decreases inflation volatility through shifting the consumption basket and the composition of exports towards high value added goods for which the terms of trade are more stable is closely related to the notion that the level of development influences volatility. Acemoglu and Zilibotti (1997) present a model in which countries with higher incomes are better able to undertake investment in indivisible forms of capital and therefore achieve a more balanced sectoral distribution of output. Empirical evidence presented by Acemoglu and Zilibotti (1997) is shown to support this prediction. Clearly, the level of development is also likely to play a role in reducing inflation volatility, and therefore in our empirical analysis we control for per capita income in testing for a relationship between openness and inflation volatility.

The above discussion has highlighted the ways in which openness may affect inflation volatility. Before describing the methods that we use in order to cast some light on these mechanisms, we close this section with a brief review of the empirical evidence on openness and other forms of macroeconomic volatility. Devereux and Lane (2003) show that bilateral nominal exchange rate volatility is negatively related to bilateral trade flows and attribute this relationship to the standard optimal currency area hypothesis that exchange rate stability is more likely to be and inflation volatility may be less strong amongst high income countries and we address this possibility in our empirical work.

${ }^{11}$ The data used for this calculation are based on 5 year observation windows, 1961 - 65 through 1996 - 2000, and cover 106 countries (the panel is unbalanced). 
pursued amongst groups of countries with strong trade links. Evidence linking openness and the volatility of GDP growth is mixed, as noted in a recent review by Winters et al. (2004). Easterly et al. (2001) estimate a positive effect of openness on growth volatility using a sample of developed and developing countries, but the effect becomes insignificant on controlling for the initial level of development. In contrast, Mobarak (2005) estimates a negative impact of openness on the volatility of output growth, while Levy-Yeyati and Sturzenegger (2003) find that the relationship is negative amongst non-industrial countries but positive amongst industrial countries.

\section{Data and methodology}

In this section we describe the data and our econometric methodology. The inflation data measure the annual rate of consumer price inflation at the quarterly frequency and are taken from International Financial Statistics (appendix B provides comprehensive notes on data sources). We compile data for an unbalanced panel of 96 countries; the longest period for which data are available for any single country is $1961: 1$ to $2000: 4 .{ }^{12}$ It is important to note that as we have defined inflation as growth in the price index over the last year rather than the last quarter there cannot be seasonal effects in the data that induce spurious volatility.

In order to measure inflation volatility we divide the data for each country into a maximum of 8 windows, each of 20 quarters (1961: 1 to $1965: 4,1966: 1$ to $1970: 4$ and so on). ${ }^{13}$ For each sub-period we then compute inflation volatility $(V I N F)$ as

$$
V I N F=\ln [1+s d(I N F)]
$$

where $s d$ is a standard deviation and $I N F$ is the decimal inflation rate (3\% inflation is

\footnotetext{
${ }^{12}$ The 96 countries correspond to the sample used by Romer (1993) in analysing the relationship between openness and mean inflation, except that we have excluded the four Gulf oil states considered by Romer, and included Chad, a country for which Romer was unable to obtain sufficient data. Appendix A lists the 96 countries included in the sample.

${ }^{13}$ The full set of time observations are typically only available for OECD countries and the larger emerging market economies. As a result, the panel that we use is unbalanced. The maximum number of time observations per country is 8 , the minimum 3 and (in the largest sample used) the average is 5.6.
} 
represented as 0.03). A standard practice in the literature is to take log transforms to downweight very large readings that may occur during hyperinflation episodes. One disadvantage of the log transform is that it overweights observations very close to zero (the log of such a reading is a large negative number). To avoid this, we consider the log of one plus the decimal standard deviation of inflation. However, later sections in this paper show that our results are robust to alternative measures of VINF.

In order for the standard deviation to be a valid measure of volatility the mean of the data must be constant over the period for which it is calculated and must not exhibit a secular trend. By measuring volatility at the five-year frequency rather than over several decades we reduce the chances of identifying spurious volatility associated with shifts in mean inflation. On the other hand, short window lengths risk confusing breaks in mean inflation with persistent shocks around a stable mean. Therefore, in checking robustness, we consider window lengths of 3 years and 8 years. ${ }^{14}$

The data for inflation volatility include some outliers, even after the transformation in (1). In order to ensure that our results are not driven by outliers we exclude observations more than three standard deviations from the mean of the unconditional distribution. This leads to 12 observations, approximately $1.5 \%$ of the sample, being dropped. These observations are mainly for Latin American countries that experienced extreme inflation during the 1980s. ${ }^{15}$

Openness is defined as the natural log of imports plus exports relative to GDP, and is denoted $O P E N .^{16}$ The log trade to GDP ratio is a frequently used proxy for openness and can arguably account for some of the core mechanisms linking openness and inflation volatility emphasised

\footnotetext{
${ }^{14} \mathrm{~A}$ further requirement for the standard deviation to be a valid measure of volatility is that the inflation rate be an $\mathrm{I}(0)$ variable rather than an $\mathrm{I}(1)$ variable. The stationarity of the inflation rate, at least within 5 year windows, is a maintained assumption in our analysis. Hendry (2001) argues strongly that the inflation rate should be treated as an $\mathrm{I}(0)$ process rather than an $\mathrm{I}(1)$ process.

${ }^{15}$ As a result of the outlier exclusion procedure Brazil and Nicaragua drop out of the sample because the estimation technique that we employ requires that three consecutive observations be available in order for a country to be included in the panel. Although these countries represent interesting examples of successful reductions in inflation volatility, our sample still includes many Latin American countries whose experiences have been similar. We argue that our findings concerning openness and inflation volatility are applicable to the Latin American experience.

${ }^{16}$ We checked $O P E N$ for outliers using the criterion applied to VINF, but none were found.
} 
in our earlier discussion. ${ }^{17}$ However, being a de facto measure of openness, it is potentially endogenous, warranting the use of instrumental variables in the estimation procedure.

Table 1 describes the evolution of inflation volatility and the trade ratio during the period $1971-2000$ for different groups of countries. ${ }^{18}$ For the largest sample of countries inflation volatility has nearly halved since the early 1970s. However, this reduction appears to be more pronounced in East Asia and Western Europe and North America. In contrast, Sub-Saharan Africa and Latin America have experienced only a marginal fall in inflation volatility since 1971 - the secular decline in inflation volatility observed in developed countries is absent. The average trade to GDP ratio has exhibited a steady increase since the early 1970s, though the experiences of individual groups of countries do vary.

In Figure 1 we plot VINF against OPEN. Even before controlling for country fixed effects, time dummies, other regressors and potential reverse causation a negative relationship between openness and inflation volatility can be observed. Each graph reveals some extreme observations, even after the steps taken to deal with outliers. However, in the robustness section we show that our main results do not depend on these observations.

\subsection{The econometric model}

In order to estimate the effect of openness on inflation volatility we consider the following model:

$$
V I N F_{i t}=\alpha+\beta V I N F_{i t-1}+\gamma O P E N_{i t}+\eta_{i}+\varepsilon_{i t}
$$

where $i$ denotes a country, $t$ a 5 year period, $\eta_{i}$ a country fixed effect and $\varepsilon_{i t}$ the error term. The lagged dependent variable in (2) controls for persistence in inflation volatility, which may be intrinsic or simply a proxy for other determinants of volatility that are omitted at this stage.

The approach to estimating (2) follows Arellano and Bond (1991) and Arellano and Bover (1995). In order to eliminate the time invariant fixed effects we take first differences of (2) to

\footnotetext{
${ }^{17}$ The use of the log transform is not crucial to our results: If we use the untransformed trade share in our regressions the main implications of our empirical analysis are unchanged.

${ }^{18}$ Table 1 focuses on 51 countries. Data for the other 45 countries in the sample start after 1971 and therefore their inclusion in Table 1 would mean that the number of countries fluctuates across the columns, something that we wish to avoid.
} 
obtain

$$
\Delta V I N F_{i t}=\beta \Delta V I N F_{i t-1}+\gamma \Delta O P E N_{i t}+\Delta \varepsilon_{i t}
$$

Estimating (3) by least squares is problematic. Firstly, the transformed error term is correlated with the lagged dependent variable (both include $\varepsilon_{i t-1}$ ) and this will lead to biased parameter estimates. Secondly, OPEN may be endogenously determined, e.g. if volatile inflation is an impediment to trade then causation will run from left to right in (3) and the impact of openness on inflation volatility will be overstated. Alternatively, there may exist a common cause for openness and inflation volatility. One possibility is that each is the result of deeper preferences that shape macroeconomic policy, whilst another is that shocks to the terms of trade affect both variables, e.g. a collapse in export prices may reduce the nominal value of exports such that $O P E N_{i t}$ falls and at the same time cause aggregate demand to change so that inflation volatility increases.

In order to address these problems Arellano and Bond (1991) suggest a generalised method of moments (GMM) technique. Assuming that the errors in equation (2) are serially uncorrelated and that the explanatory variables are uncorrelated with future realisations of the errors (their endogeneity implies that they are correlated with only current values of the errors) lags of VINF and $O P E N$ dated $t-2$ and earlier are valid instruments with which to identify the exogenous variation in openness. ${ }^{19}$ A potential drawback of this Differenced-GMM estimator is that in the presence of high time-series persistence and short panels, lagged levels of the variables may be poor instruments for subsequent first differences, leading to finite sample biases (Blundell and Bond 1998). An alternative approach, suggested by Arellano and Bover (1995) and Blundell and Bond (1998), is the System-GMM estimator, which uses lagged differences of each variable as instruments in estimating the levels relationship in (2), and combines this information with the Differenced-GMM estimates of equation (3). The validity of these instruments requires a constant correlation between $V I N F_{i t}$ and the fixed effect, and between $O P E N_{i t}$ and the fixed effect. If this is the case, $\triangle V I N F_{i t-1}$ and $\triangle O P E N_{i t-1}$ are orthogonal to future realisations of

\footnotetext{
${ }^{19}$ To be precise, the GMM estimator for equation (3) uses the following moment conditions: $E\left(V I N F_{i, t-s} \Delta \varepsilon_{i t}\right)=0 ; E\left(O P E N_{i, t-s} \Delta \varepsilon_{i t}\right)=0$ for $t=3,4, \ldots T$, and $s \geqq 2$.
} 
the error terms and represent valid instruments for estimating the parameters of (2). ${ }^{20}$

In implementing the System-GMM estimator we utilise external instruments based on lagged values of log population size, $P O P$. This term is the time-varying element of a standard gravity model of trade flows; see for example Frankel and Romer (1999). Although gravity equations typically use population size to explain cross-sectional differences in openness, we find that past population size helps to predict the evolution of openness and can therefore be used to increase the efficiency of the GMM estimator. The role of the external instrument is further examined in the discussion of the empirical results in Section 4.

The validity of the instruments can be evaluated using the Sargan test of over-identifying restrictions and Lagrange Multiplier tests for the absence of second order serial correlation (Arellano and Bond 1991). It is important to note that the first differenced transformation yielding (3) induces an MA(1) error structure, and therefore we expect that the first-differenced residuals will be negatively autocorrelated at the first lag but uncorrelated at the second lag. The estimated standard errors take account of the first-order negative autocorrelation and any heteroscedasticity in the residuals, see Arellano and Bond (1991). As recommended by Blundell and Bond (1998) the estimates that we report are based on 1-step GMM estimation in which equal weight is placed on each moment condition. ${ }^{21}$

\section{Empirical results}

In Table 2 we present our basic empirical results. Columns $1-4$ list the ordinary least squares (OLS), within groups (WG), Differenced-GMM and System-GMM estimates of a model in which inflation volatility depends on its own lag and openness, plus a full set of time dummies. The Differenced-GMM estimates use as instruments $V I N F_{t-2}, O P E N_{t-2}, P O P_{t-2}$ and $P O P_{t-3}$ and the System-GMM estimates use as additional instruments $\triangle O P E N_{t-1}$ and $\triangle P O P_{t-2} \cdot{ }^{22}$ In each

\footnotetext{
${ }^{20}$ Specifically, the following additional moment conditions are available: $E\left(\Delta V I N F_{i t-s}\left(\eta_{i}+\varepsilon_{i t}\right)\right)=0$ for $s=1$ and $E\left(\triangle O P E N_{i t-s}\left(\eta_{i}+\varepsilon_{i t}\right)\right)=0$ for $s=1$.

${ }^{21}$ All estimations are conducted using the DPD package in Pc-Give, see Doornik and Hendry (2001).

${ }^{22}$ The differenced lagged dependent variable is not used as an instrument in the levels part of the system estimator because the marginal restrictions required in order for it to be a valid instrument were rejected by a Sargan test. It appears that there has been some 'inflation volatility convergence' during the sample period -
} 
case the effect of openness on inflation volatility is negative and this relationship is propagated through time by the positively signed autoregressive term.

The model that we emphasise is the System-GMM estimate in column 4 which shows that OPEN impacts VINF with a coefficient of -.086 . The within groups standard deviation of openness is 0.198 while that for inflation volatility is $0.067 .{ }^{23}$ Hence, a one standard deviation increase in openness yields a 0.25 standard deviation reduction in inflation volatility in the first 5 years. It should be noted, however, that additional controls have not yet been introduced. In the second part of this section we show that including further controls reduces the openness coefficient by one half, leaving a modest effect.

Before investigating the robustness of our results we consider the properties of the instruments. The Sargan test for the validity of the over-identifying moment conditions used in column 4 yields a p-value of $35 \%$. In order to check that this outcome is not a Type II error based on pooling valid and invalid instruments we perform separate Difference-Sargan (D-Sargan) tests for the moment conditions associated with each variable. The p-values are $20 \%$ (VINF), $76 \%$ $(O P E N)$ and $34 \%(P O P)$, suggesting that each type of instrument is individually valid. Furthermore, the $\operatorname{AR}(1)$ and $\operatorname{AR}(2)$ tests provide strong support for the hypothesis that the errors in (2) are serially uncorrelated, a necessary condition for instrument validity.

A related question concerns the explanatory power of the instruments. If the instruments are weak the exogenous variation in openness will be limited and this may distort inference (Stock, Wright and Yogo 2002). To address this issue we regressed $\triangle V I N F_{t-1}$ and $\triangle O P E N_{i t}$ on the instruments used for the differenced equation, and $V I N F_{t-1}$ and $O P E N_{t}$ on the instruments used for the levels equation, and performed F-tests for the joint significance of the regressors. The test statistics were 27.96 ( $\triangle V I N F_{t-1}$ equation), $23.16\left(\triangle O P E N_{i t}\right), 20.04\left(V I N F_{t-1}\right)$ and $83.29\left(O P E N_{t}\right)$, each of which is significant at the $0.1 \%$ level. ${ }^{24}$ Hence, the instruments appear to have considerable explanatory power. On a related theme, Blundell and Bond (1998) show that a GMM estimate of the autoregressive parameter that is close to the WG estimate typically countries with initially high volatility experience relatively large reductions in volatility during later periods. This implies that $\triangle V I N F_{i t-1}$ is not orthogonal to $\eta_{i}$ in equation (2).

${ }^{23}$ These statistics are calculated from the residuals obtained by regressing openness and inflation volatility on a full set of country dummies.

${ }^{24}$ Each regression contained a full set of period dummies, but these dummies are not included in the F-tests. 
reflects a problem of weak instruments. The centrality of the Differenced-GMM and System$G M M$ estimates with respect to the OLS-WG range is further evidence that our results are not due to weak instruments.

In the final two columns of Table 2 we take a further look at the role of the external instrument, $P O P$. In column 5 all terms in $P O P$ are dropped from the instrument set. A comparison of these results with those in column 4 indicates that the main role of $P O P$ is to increase the efficiency of the estimation. This is seen most clearly in the case of the openness effect, which is actually of greater magnitude in column 5 than in column 4 but yields a smaller $t$-ratio because its standard error increases three-fold. Hence, the external instrument does not induce the sign or magnitude of $O P E N$ but instead increases the precision of the estimation. In column 6 we address the possibility that the significance of $O P E N$ is due to $P O P$ having been excluded from the regressors. The results indicate that this is not the case. Instead, changes in population size matter for inflation volatility only through inducing a change in openness, i.e. POP satisfies the standard requirements of an instrumental variable.

\subsection{Robustness: Adding further controls}

In this sub-section we add further controls to the basic model. The largest sample for which all of the regressors are available comprises 451 observations drawn from 84 countries and this is the sample that we use in each column of Table 3 (the 12 countries that drop out of the 96 country sample used in Table 2 are listed in appendix A). In order to conserve space we focus on the System-GMM estimates.

The first column reproduces the simple specification for the new sample size. The magnitude of each coefficient falls slightly but the qualitative results are robust. Column 2 controls for the natural $\log$ of one plus mean inflation $(I N F)$ and uses as instruments $I N F_{t-3}$ and $\Delta I N F_{t-2}$ (instruments at shorter lags are invalid according to a D-Sargan test). Mean inflation is highly significant, reflecting its strong correlation with inflation volatility. The openness coefficient falls to -.044 , a little more than half its value in column 4 of Table 2, but owing to greater precision in the estimation it remains significant at the $5 \%$ level, i.e. openness reduces inflation volatility even amongst countries that have the same average inflation. The autoregressive parameter is 
close to zero after controlling for mean inflation. Indeed, deleting the autoregressive term from column 2 leaves the results practically unchanged - the openness coefficient remains -.044 and the $t$-ratio is 2.26 (static estimates of regressions $3-10$ are reported in Table A2 in the special appendix for referees). ${ }^{25}$

We experimented with two variations on the column 2 specification. Firstly, given the important relationship between mean inflation and inflation volatility, we defined the regression in terms of the log coefficient of variation for inflation (the standard deviation of inflation relative to mean inflation). A GMM-SYS regression of this term on its first lag plus openness yields an openness effect that is significant at the $5 \%$ level. Secondly, we experimented with a non-linear relationship between the first two moments of inflation: Adding the square of mean inflation to column 2 gives an openness coefficient of -.041 and a corresponding t-ratio of 2.11 (full details of these two experiments are available on request).

In column 3 we control for the natural log of GDP per capita $(R G D P)$ and add the second lag of that variable to the instruments. ${ }^{26}$ This is measured in 1996 US $\$$ and corresponds to the first year from each of the 5 year windows for which inflation volatility is measured. The effect of $R G D P$ is negative but close to zero. Further (unreported) experimentation shows that this is due to $I N F$ having been included in the regression (the effect of $R G D P$ is entirely mediated through mean inflation). The openness coefficient is further diminished relative to column 1 but is significant at the $6 \%$ level. Column 4 controls for the log product of population and per capita income, a measure of economic size. This is a potentially important control when analysing the effects of openness, see Lane (1997), but does not change the picture in this case.

We next address the possibility that openness exerts different effects on primary commodity exporters. In section 2 we noted that greater openness may increase volatility, or reduce it by less, if openness implies expansion in markets for primary commodities, which are relatively volatile. The dummy PRIMEXP is equal to unity for countries for which more than $50 \%$ of

\footnotetext{
${ }^{25}$ It should be noted that although originally proposed for dynamic panel models, the System-GMM technique is an efficient estimator for static panels and has often been used in this context, see Beck (2002).

${ }^{26}$ Unless otherwise stated, regressions $3-9$ use the second lag of the marginal variable as an additional instrument. Instruments based on lagged first differences of the marginal terms are not used because we found that in some specifications the Sargan p-value was close to unity, which is a sign that the instrument set is too large and that estimation may be imprecise.
} 
exports during the period 1988 - 92 are fuels or other primary commodities, and zero otherwise. In column 5 the negative impact of openness on inflation volatility is smaller amongst primary commodity exporters, but the interaction term is insignificant and the main conclusion is that the overall effect of openness is negative amongst both groups of countries. ${ }^{27}$

In section 2 we also noted that openness may increase inflation volatility if it is associated with increased financial flows, which are often pro-cyclical and can amplify volatility. Measures of financial openness such as foreign direct investment relative to GDP turn out insignificant, whereas trade openness becomes more negative and is significant at the $1 \%$ level, indicating that financial variables may control for one mechanism through which openness increases volatility (results are presented in a special appendix for referees).

The next idea that we explore is that movements in inflation volatility result from changes in the size of economic shocks. This is the 'good luck' hypothesis in the literature on volatility in the United States, see Ahmed, Levin and Wilson (2002). We control for the natural log of one plus the decimal standard deviation of annual output growth $(V O L)$. If smaller supply and demand shocks drive output and inflation volatility, and the link between openness and inflation volatility is coincidental, the augmented regression should reveal this fact. In column 6 openness remains significant at the $5 \%$ level while output volatility is insignificant.

The weak effect of output volatility could be due to supply shocks that reduce output growth and raise inflation. In the aftermath of such shocks a policy authority can trade-off higher output volatility for lower inflation volatility, or vice versa, through shifting aggregate demand. This may weaken the positive association between output and inflation variance. In column 7 we control for the natural log of one plus the decimal standard deviation of the trade weighted mean of output growth in the five largest trading partners of each country (TPVOL), which is generally beyond the control of the domestic policy authority. The effect of $T P V O L$ is stronger than that of $V O L$ (the large point estimate is due to the very small standard deviation of $T P V O L$ ). We also estimated (but do not report) a model interacting TPVOL with $O P E N$, to allow inflation volatility to be more responsive to foreign GDP volatility in more open economies. This term generated a coefficient of $0.555(t=2.03)$, while the coefficient for OPEN was -.050

\footnotetext{
${ }^{27} \mathrm{~A}$ caveat that should be added here is that PRIMEXP is time invariant. A better measure would allow for time variation in this index.
} 
$(t=2.43)$. The mean of $T P V O L$ is .02 , which implies that the total marginal effect of $O P E N$ is negative, even though it appears that sensitivity to global shocks is one channel through which openness can increase inflation volatility.

In column 8 we control for the natural log of one plus the black market exchange rate premium $(B M P)$, defined as the percentage markup of the black market exchange rate over the official rate. This is regarded as a measure of market distortions, and the policies that induce these distortions may also be a source of inflation volatility. More specifically, controlling for $B M P$ may shed some light on an alternative interpretation of our results, which is that they are a by-product of policy reforms implemented in return for assistance from bodies such as the International Monetary Fund (IMF). Such reforms often require that countries remove trade barriers and adopt more disciplined fiscal and monetary policy, which will reduce inflation volatility. The black market premium is regarded as a measure of the intensity of market distortions and is therefore likely to be inversely related to success in implementing reforms. The fact that $O P E N$ remains significant when controlling for $B M P$ suggests that the negative relationship between openness and inflation volatility is not simply a by-product of pro-market reforms. ${ }^{28}$

In column 9 we control for the natural log of one plus the average rate of economic growth ( GROWTH $)$, the rationale being that during 'good times' inflation volatility may be more easy to control. The results indicate some evidence for this and the openness effect is diminished and is significant at only the $10 \%$ level. However, in the next column we pool all of the controls used in Table 3 and find that $O P E N$ is significant at the $5 \%$ level.

Additional robustness checks are reported in the special appendix. We consider alternative definitions of inflation volatility and openness and numerous controls, including financial depth, an index of political constraints, government size and climatic volatility. The negative effect of openness is robust in each case.

\footnotetext{
${ }^{28}$ The insignificance of $B M P$ is surprising, but turns out to be a consequence of controlling for mean inflation. If mean inflation is removed from column 8 the t-ratio for $B M P$ rises to 1.97 .
} 


\subsection{The role of the exchange rate regime}

A fixed exchange rate combined with capital mobility is thought to restrict discretionary monetary policy by forcing a country to adopt foreign monetary policy. This may reduce inflation volatility. Alfaro (2005) finds that the exchange rate regime (not openness) explains average inflation performance. On the other hand Tornell and Velasco (2000) show that fixed rates can induce fiscal laxity, and this may increase volatility. Bleaney and Fielding (2002) present a model in which tighter exchange rate pegs reduce inflation volatility except in the case of the multi-lateral pegs maintained by the Francophone countries in Africa, which increase volatility because the peg prevents monetary authorities from offsetting the effects of external shocks.

We consider the de facto exchange rate regime classification proposed by Reinhart and Rogoff (2004). This provides an index in the range $1-4$ where 4 denotes greatest exchange rate flexibility. ${ }^{29}$ In contrast to the official IMF classification the Reinhart-Rogoff scheme is based on actual exchange rate movements rather than the policy a central bank claims to have followed. Furthermore, the Reinhart-Rogoff scheme incorporates information on black market currency exchange in addition to official purchases. ${ }^{30}$

In column 1 of Table 4 we add the exchange rate regime indicator (XRATE) to our baseline regression and in column 2 we add the square of the exchange rate regime in order to test for non-linearities of the sort discussed by Bleaney and Fielding (2002). The additional control does not alter the role of openness and is statistically insignificant. Adding mean inflation to the column 1 specification induces a negative sign for XRATE that is significant at the $10 \%$ level. This may occur because the effect of a fixed exchange rate in restricting discretionary policy is reflected in mean inflation, such that after controlling for $I N F$ the partial effect of $X R A T E$ captures only the increases in volatility that occur if fixed rates restrict stabilisation

\footnotetext{
${ }^{29} \mathrm{~A}$ fifth category is also available but this refers to countries with 'freely falling' rates. One criterion for identifying such cases is an inflation rate above $40 \%$, i.e. a large positive inflation shock automatically places a country in the top tier and therefore this category will be highly endogenous. Consequently we focus on categories $1-4$.

${ }^{30}$ In an important study, Levy-Yeyati and Sturzenegger (2003) propose an alternative de facto classification of the exchange rate regime that utilises information on currency reserves in addition to the nominal exchange rate. However, this index is available for fewer countries than the Reinhart-Rogoff classification.
} 
policies.

A potential problem with these results is that the instruments for $X R A T E$ may be ineffective given that it is a discrete variable. In column 4 we use the $X R A T E$ information in a different way. We restrict the sample to those observations for which $X R A T E$ is defined as a peg or a peg with bands that stretch $2 \%$ either side of the target. The openness term retains its significance in this sample of fixed and semi-fixed exchange rates. This finding provides some evidence against the hypothesis that our results arise only because increased openness happens to have been associated with a reduction in inflation volatility arising from reduced pass-through from exchange rates to consumer prices. As changes in pass-through are unlikely to have been an important driver of inflation volatility in cases in which exchange rate fluctuations have been minimal the relationship between openness and inflation volatility is hard to interpret as the result of failure to control for changes in pass-through.

In columns $5-8$ we side-step the issue of how to instrument the exchange rate regime by reporting within groups estimates. The results in column 5 indicate a much stronger positive effect of the exchange rate regime in this case (compare the results with those in column 1). However, this relationship disappears on controlling for mean inflation. In columns 7 and 8 the evidence for a U-shaped effect of XRATE remains weak. In contrast, the effect of openness on inflation volatility is quite robust in all cases.

\subsection{Robustness across sub-samples}

Table 6 presents results for various sub-samples. In column 1 we exclude the $5 \%$ most extreme values for inflation volatility and openness $(2.5 \%$ from each tail of each unconditional distribution). This means that Hong Kong and Singapore are omitted from the sample, an important robustness check given that trade ratios may overstate the openness of these countries because many imports are almost immediately exported. The effect of openness is robust.

In column 2 we exclude the 38 countries that are not awarded at least a grade $\mathrm{C}$ for data quality by Summers and Heston (1988). Openness is significant at the $5 \%$ level, suggesting that our basic findings are not due to low data quality in closed economies inducing spurious volatility. 
The next sub-sample comprises the 68 low debt countries listed in Terra (1998). Terra argues that the negative relationship between the levels of openness and inflation exists only amongst heavily indebted countries; here we investigate whether the same is true of openness and inflation volatility. Openness is significant at the $5 \%$ level and its coefficient is of similar magnitude to those obtained in Table 3.

In column 4 we omit the 20 countries that maintained an inflation targeting regime during some part of the sample (dates are taken from Fatas, Mihov and Rose 2004). ${ }^{31}$ The openness effect is robust, suggesting that our main results are not due to inflation targeting schemes having caused a reduction in inflation volatility and such changes being correlated with openness by chance.

The next hypothesis that we address is that our results arise because structural adjustment programmes associated with IMF/World Bank loans secure both macroeconomic stability and trade openness. In column 5 we exclude 18 countries identified by Easterly (2005) as being amongst the top 20 recipients of IMF and World Bank loans (the other two countries, Bangladesh and Mali, are not part of our sample). The negative effect of openness remains intact, suggesting that our results do not depend on the effects of IMF/World Bank interventions.

Column 6 focuses on 71 developing and emerging market economies. ${ }^{32}$ The effect of openness is larger and more significant in the developing country sample than in the full sample. The opposite is true in column 7 , which looks only at the 23 OECD countries excluded from the column 6 sample $\left(\triangle R G D P_{t-1}\right.$ is added to the instruments used in column 7 because initial results indicated very imprecise estimation). These results may arise because there exist reasons to pursue inflation stability in OECD countries even in the absence of openness, e.g. Posen (1993) emphasises the importance of financial sector opposition to inflation in industrial countries. Similarly, consumption and production in OECD countries may have been concentrated in high value added sectors at the start of the sample, in which case greater trade openness may be less

\footnotetext{
${ }^{31}$ Two countries, South Africa and Thailand, adopted inflation targeting during 2000, the final year of the sample. As a reform occurring in this year is unlikely to affect our results we do not exclude these countries.

${ }^{32}$ These are the 96 countries in the core sample minus 23 countries that have been OECD members since 1961. Turkey has been an OECD member since 1961, but we include Turkey in the 71 country sub-sample on the grounds that it is best regarded as an emerging market economy. Hong Kong and Singapore are excluded even though they are not OECD members (including these two countries does not change the results).
} 
likely to reduce inflation volatility by promoting structural change in this direction.

\subsection{Robustness to varying the data frequency}

In Table 6 we consider the sensitivity of our results to changing the data frequency. Column 1 uses a measure of inflation volatility based on 5 year windows but calculated from annual rather than quarterly data. Although quarterly data provide more observations for calculating volatility, they may be subject to larger measurement errors than the annual data. The effect of openness in column 1 is similar to that obtained for equivalent specifications based on quarterly data, however, suggesting that possible measurement errors in quarterly data do not drive our results.

The second column of Table 6 measures inflation volatility using quarterly data and 8 year windows (1961-68, 1969-76 and so on) whilst the third column uses 3 year windows (1961-63, $1964-66$ and so on). If the 5 year window is too short, in that shocks to inflation are not given time to dissipate, volatility may be understated because a shock with long-lived effects would be recorded as a shift in the mean and limited variation around that mean, not high variation around a stable mean. On the other hand, if shocks dissipate quickly but there are regular shifts in mean inflation, 5 year windows may span these breaks, leading to spurious volatility. The results for alternative window lengths show that the effect of openness is preserved and in each case the relationship is more significant than that obtained using 5 year windows (the puzzling AR(1) outcome in column 2 may reflect low test power in the small sample associated with 8 year windows).

\section{Channels linking openness and inflation volatility}

In this section we explore channels through which openness may decrease inflation volatility. The first idea that we discussed in section 2 was that openness increases the costs of inflation volatility and therefore provides an incentive for governments to restrict policies that induce volatility in money supply growth and inflation, e.g. recourse to seigniorage during periods of fiscal deficit. In order to investigate this hypothesis we augment the inflation volatility regressions with a measure of monetary volatility, calculated as the log of one plus the standard deviation of the 
annual growth rate of money plus quasi-money $(V M O N) \cdot{ }^{33}$ If greater monetary stability is one of the channels through which openness lowers inflation volatility then on holding constant $V M O N$ the effect of openness should diminish. The results are based on GMM-SYS estimation in order to deal with potential reverse causation from inflation volatility to monetary volatility and are reported in Table 7. A constant sample of 344 observations (the largest common sample for these variables) is used throughout. The first regression demonstrates that the effect of openness is similar to that estimated previously. Column 2 adds $V M O N$. The new term is significant at the $5 \%$ level while the coefficient multiplying openness is reduced by one third and is insignificant at the $10 \%$ level. This evidence is consistent with the hypothesis that openness induces greater stability in inflation through restricting the volatility of money supply growth.

A second channel through which openness can reduce inflation volatility is promoting structural change in consumption and production, towards high value added goods for which world prices (and hence the terms of trade) are more stable. In column 3 we explore this hypothesis by adding to the baseline regression the term VTOT, defined as the log of one plus the standard deviation of the annual growth rate of the export price deflator relative to the import price deflator. ${ }^{34}$ The VTOT term is significant and its inclusion reduces the openness coefficient by more than one half, such that it is insignificant at the $25 \%$ level. This evidence is consistent with the hypothesis that openness decreases inflation volatility through inducing greater stability in import prices and export prices, possibly through shifting trade towards high value added goods via the mechanisms discussed in section 2 .

In column 4 both VMON and VTOT are included in the model. Monetary volatility is significant at the $10 \%$ level and terms of trade volatility at the $5 \%$ level, while the openness coefficient is only a little more than one third its size in column $1 .{ }^{35}$ These results suggest that both channels are relevant in explaining the negative impact of openness on inflation volatility. In columns 5-8 we replicate regressions $1-4$ but include domestic output volatility as a further control. If anything, the roles of monetary and terms of trade volatility in accounting for the

\footnotetext{
${ }^{33}$ Underlying data are annual.

${ }^{34}$ Underlying data are annual.

${ }^{35}$ If these regressions are extended to include the average growth rate of the money supply and the average growth rate of the terms of trade the conclusions drawn concerning the relationship between openness and inflation volatility become stronger.
} 
relationship between openness and inflation volatility are more powerful in this case.

In order to further investigate the monetary volatility and terms of trade volatility channels we present models for the determinants of these two intermediate variables in Table 8. In column 1 we report a GMM-SYS estimate of a regression in which monetary volatility depends on its own lagged value and openness. Monetary volatility decreases with openness and this finding survives the inclusion of additional controls in column 2, including the average growth rate of the money supply $(M O N)$.

A more precise test of the hypothesis that openness reduces monetary and inflation volatility through reducing the propensity for governments to use seigniorage during periods of fiscal stress is presented in column 3. The term VSEIGN is the log of one plus the decimal standard deviation of the percentage growth rate of reserve money. This is the narrow measure of the money supply that governments vary in order to raise seigniorage and is frequently used as a basis for measuring seigniorage in empirical work, see for example Aisen and Veiga (2005a). The volatility of the percentage growth rate of reserve money depends negatively on openness in a parsimonious specification in which the controls are the average growth rate of reserve money $(S E I G N)$ and the first lag of VSEIGN. Furthermore, the effect is significant at the $1 \%$ level. In column 4 the addition of other controls weakens this relationship but it remains significant at the $10 \%$ level. Hence, the evidence suggests that trade openness reduces the volatility of reserve money growth, possibly because governments in relatively open economies use seigniorage less frequently in smoothing revenues. This then restricts the volatility of the aggregate money supply, which in turn restricts the volatility of inflation.

We also tried augmenting the baseline inflation volatility regressions with the volatility of reserve money growth, $V S E I G N$, i.e. an exercise analogous to those performed for $V M O N$ and VTOT and reported in Table 7. As expected, this reduced the size of the openness coefficient such that it was insignificant at the $5 \%$ level. However, the VSEIGN term, though positive, was also insignificant at conventional levels. This indicates that the link between the volatility of narrow money and the volatility of inflation is less strong than the link between the volatility of broad money growth $(V M O N)$ and the volatility of inflation. However, we also found that VSEIGN exerts a positive and significant effect on VMON in GMM-SYS regressions. This 
suggests that the mechanism through which openness reduces inflation volatility is through first decreasing the volatility of reserve money growth. This restricts the volatility of broad money growth, which then restricts the volatility of inflation.

In columns 5 and 6 of Table 8 we present models for the volatility of the growth rate of the terms of trade. The $O P E N$ term is negatively signed and significant even after controlling for the average growth rate of the terms of trade, TOT. A caveat to note is that whilst openness appears to reduce the average size of terms of trade shocks it may cause domestic inflation to be more sensitive to those shocks. The overall effect of openness occurring via the terms of trade channel would then be ambiguous. The fact that the addition of VTOT to the inflation volatility regressions in Table 7 reduced the size of the $O P E N$ coefficient suggests that the role of openness in restricting terms of trade volatility dominates any positive effect arising from increased exposure to shocks.

Overall, whilst the evidence presented here cannot prove that openness reduces inflation volatility through restricting monetary volatility or through changing the structure of consumption and production in favour of goods whose prices are more stable, the results are at least consistent with those hypotheses.

\section{$6 \quad$ Summary and concluding remarks}

In this paper we have examined the evidence linking trade openness and inflation volatility. The econometric approach used pre-determined variables as instruments in order to identify the exogenous variation in openness. The principal finding was that countries that have opened up to trade more rapidly than the global average have experienced larger reductions in inflation volatility. The relationship is consistently significant at the $5 \%$ level, although in the most general regressions that we consider the quantitative importance of the relationship is quite modest, for instance a one standard deviation increase in openness implies only a 0.13 standard deviation reduction in inflation volatility. However, this is a lower bound on the magnitude of the relationship given that openness may influence many of the controls that we considered, e.g. the average rate of inflation and per capita income.

We found that openness reduces inflation volatility amongst fixed exchange rate and flex- 
ible exchange rate countries, suggesting that our results are unlikely the by-product of open economies choosing fixed exchange rates and fixed rates delivering inflation stability. Sub-sample regressions were used to cast doubt on scenarios in which our results are induced by outliers, poor data quality, the experiences of heavily indebted countries, the adoption of inflation targeting and IMF or World Bank interventions. Finally, we demonstrated that the negative effect of openness on inflation volatility is robust to measuring volatility over different time intervals.

An important theme of the paper has been the need to pin down channels linking openness and inflation volatility. Two possibilities were emphasised. Firstly, if governments and central banks believe that inflation volatility is especially costly in open economies, e.g. because it undermines the competitiveness of firms in the tradables sector, they are less likely to resort to seigniorage during periods in which revenues from conventional sources of taxation are temporarily reduced. This will then restrict the volatility of broad money growth and hence inflation. Secondly, openness may change the structure of consumption and production, towards goods whose prices are more stable internationally. This decreases terms of trade volatility and therefore inflation volatility. Our results showed a weaker link between openness and inflation volatility on holding constant monetary and terms of trade volatility, a finding that is consistent with these two arguments. In combination, the two channels appear to dominate any positive effect of openness on inflation volatility arising from greater exposure to global shocks. The fact that these two channels are likely to be stronger in developing countries than industrial countries provides one explanation for the absence of a clear relationship between openness and inflation volatility amongst OECD countries.

Our findings cast interesting new light on the relationship between openness and macroeconomic volatility. In particular, the impact of stronger trading links on nominal forms of macroeconomic volatility such as inflation appears much stronger than its impact on the volatility of real variables such as output growth. An important challenge for future research will be to explore these differences in greater detail and to develop explanations for them based on observable country characteristics. 


\section{References}

Acemoglu, Daron and Fabrizio Zilibotti (1997). "Was Prometheus Unbound by Chance? Risk, Diversification, and Growth." Journal of Political Economy, 709-51.

Aghion, Philippe, Philippe Bacchetta and Abhijit Banerjee (2004). "Financial Development and the Instability of Open Economies." Journal of Monetary Economics, 1077-1106.

Ahmed, Shagil, Andrew Levin and Beth Anne Wilson (2002). "Recent U.S. Macroeconomic Stability: Good Policies, Good Practices, or Good Luck?" Review of Economics and Statistics, 824-32.

Aisen, Ari and Francisco Veiga (2005a). "The Political Economy of Seigniorage." Working paper number 12/2005, Universidade do Minho.

Aisen, Ari and Francisco Veiga (2005b). "Does political instability lead to higher inflation? A panel data analysis." Journal of Money, Credit and Banking, forthcoming.

Alfaro, Laura (2005). "Inflation, Openness, and Exchange Rate Regimes: The Quest for Short-term Commitment." Journal of Development Economics, 229-49.

Arellano, Manuel and Stephen Bond (1991). "Some Tests of Specification for Panel Data: Monte Carlo Evidence and an Application to Employment Equations." Review of Economic Studies, 277-97.

Arellano, Manuel and Olympia Bover (1995). "Another Look at the Instrumental Variable Estimation of Error Component Models." Journal of Econometrics, 29-52.

Aron, Janine and John Muellbauer (2000). "Inflation and output forecasts for South Africa: Monetary transmission implications." Working paper no. 23, Centre for the Study of African Economies, University of Oxford.

Baxter, Marianne and Michael Kouparitsas (2000). "What can account for fluctuations in the terms of trade?" Working paper no. 25, Federal Reserve Bank of Chicago.

Beck, Thorsten, Asli Demirguc-Kunt and Ross Levine (1999). "A New Database on Financial Development and Structure.” Working paper no. 2146, World Bank Policy Research.

Beck, Thorsten (2002). "Financial Development and International Trade. Is There a Link?" Journal of International Economics, 107-31.

Blanchard, Olivier and John Simon (2001). "The Long and Large Decline in U.S. Output 
Volatility." Brookings Papers on Economic Activity, 135-64.

Bleaney, M. (1999). "The disappearing openness-inflation relationship: a cross-country analysis of inflation rates." IMF working paper 99/161.

Bleaney, Michael and David Fielding (2002). "Exchange Rate Regimes, Inflation and Output Volatility in Developing Countries." Journal of Development Economics, 233-45.

Blundell, Richard and Stephen Bond (1998). "Initial Conditions and Moment Restrictions in Dynamic Panel Data Models." Journal of Econometrics, 115-43.

Brahmbhatt, M. and U. Dadush (1996). "Disparities in Global Integration." Finance and Development, 47-50.

Breinlich, Holger (2005). "Economic Geography and Industrialization." Mimeo, London School of Economics.

Buraschi, Andrea and Alexei Jiltsov (2005). "Inflation Risk Premia and the Expectations Hypothesis." Journal of Financial Economics, 429-90.

Byrne, Joseph, and Philip Davis (2004). "Permanent and temporary inflation uncertainty and investment in the United States." Economics Letters, 271-77.

Catao, Luis and Marco Terrones (2005). "Fiscal deficits and inflation." Journal of Monetary Economics, 529-54.

Chen, Natalie, Jean Imbs and Andrew Scott (2004). "Competition, Globalization and the Decline of Inflation." Mimeo, London Business School and University of Warwick.

Click, Reid (1998). "Seigniorage in a cross-section of countries." Journal of Money, Credit and Banking, 154-71.

Collier, Paul, Jan Gunning and associates (1999). Trade Shocks in Developing Countries, vols 1\&2. Eds. Oxford University Press, Oxford.

Devereux, Michael and Philip Lane (2003). "Understanding bilateral exchange rate volatility." Journal of International Economics, 109-32.

Dollar, David (1992). "Outward Oriented Developing Countries Really Do Grow More Rapidly: Evidence from 95 LDCs, 1976-85." Economic Development and Cultural Change, 52344.

Doornik, Jurgen and David Hendry (2001). Econometric Modelling Using PcGive: Volume 
III. Timberlakelake Consultants Ltd, London.

Easterly, William, Roumeen Islam and Joseph Stiglitz (2001). "Shaken and Stirred: Explaining Growth Volatility." Annual World Bank Conference on Development Economics, ed. by B. Pleskovic and N. Stern.

Easterly, William (2005). "What did structural adjustment adjust? The association of policies and growth with repeated IMF and World Bank adjustment loans." Journal of Development Economics, 1-22.

Elder, John (2004). "Another Perspective on the Effects of Inflation Uncertainty." Journal of Money, Credit and Banking, 911-28.

Fatas, Antonio and Ilian Mihov (2001). "Government Size and Automatic Stabilisers: International and Intranational Evidence." Journal of International Economics, 3-28.

Fatas, Antonio, Ilian Mihov and Andrew Rose (2004). "Quantitative Goals for Monetary Policy." NBER working paper no. 10846.

Frankel, Jeffrey and David Romer (1999). "Does Trade Cause Growth?" American Economic Review, 379-99.

Gruben, William and Darryl McLeod (2004). "The Openness-Inflation Puzzle Revisited." Applied Economics Letters, 465-68.

Gwartney, James and Robert Lawson (2002). Economic Freedom of the World - 2002 Annual Report. Fraser Institute, Vancouver.

Hendry, David (2001). "Modelling UK Inflation, 1875-1991." Journal of Applied Econometrics, 16, 255-75.

Henisz (2000). "The institutional environment for economic growth." Economics and Politics, 1954-85.

Hausmann, Ricardo and Michael Gavin (1996). "Securing Stability and Growth in a Shock Prone Region: The Policy Challenge for Latin America" in Hausmann, Ricardo and Reisen, Helmut (eds.) Securing stability and growth in Latin America:Policy issues and prospects for shock prone economies. Organisation for Economic Co-operation and Development, Paris, 23-64.

Joshi, Vijay and Ian Little (1994). "India: Macroeconomics and political economy 19641991." Oxford University Press, World Bank, Washington D.C. 
Lal, Deepak and Hla Myint (1996). The Political Economy of Poverty, Equity and Growth. Oxford University Press, New York.

Lane, Philip (1997). "Inflation in Open Economies." Journal of International Economics, $327-47$.

Levy-Yeyati, Eduardo and Federico Sturzenegger (2003). "To Float or to Fix: Evidence on the Impact of Exchange Rate Regimes on Growth." American Economic Review, 1173-93.

Little, Ian, Richard Cooper, Max Corden and Sarath Rajapatirana. Boom, crisis and adjustment: the macroeconomic experience of developing countries. Oxford University Press, Oxford.

Lo, Melody, Man Chiu Sunny Wong and Jim Granato (2005). "Testing Monetary Policy Intentions in Open Economies." Forthcoming, Southern Economic Journal.

Loungani, Prakash and Phillip Swagel (2001). "Sources of Inflation in Developing Countries." IMF working paper 01-198.

Mobarak, Ahmed Mushfiq (2005). "Determinants of Volatility and Implications for Economic Development." Review of Economics and Statistics, forthcoming.

Posen, Adam (1993). "Why central bank independence does not cause low inflation: there is no institutional fix for politics." In O' Brien, R. ed. Finance and the International economy, Oxford University Press, Oxford.

Prasad, Rogoff, Wei and Kose (2004). "Financial Globalization, Growth and Volatility in Developing Countries." NBER working paper, no. 10942.

Razin, Assaf (2004). "Globalization and Disinflation: A Note." CEPR working paper no. 4826.

Reinhart, C. and K. Rogoff (2004). "The Modern History of Exchange Rate Arrangements: A Reinterpretation." Quarterly Journal of Economics, 119, 1-48.

Rogoff, Kenneth (1985). "The Optimal Degree of Commitment to an Intermediate Monetary Target." Quarterly Journal of Economics, 100, 1169-89.

Rogoff, Kenneth (2003). "Globalization and Global Disinflation." Paper presented for Federal Reserve Bank of Kansas, 2003 Jackson Hole Conference.

Romer, David (1993). "Openness and Inflation: Theory and Evidence." Quarterly Journal of Economics, 869-903. 
Sachsida, Adolfo, Francisco Galrao Carneiro and Paulo Loureiro (2003). "Does greater trade openness reduce inflation? Further evidence using panel data techniques." Economics Letters $81,315-19$.

Satyanath, Shanker and Arvind Subramanian (2004). "What determines long-run macroeconomic stability? Democratic institutions." Mimeo, New York University.

State Bank of Pakistan (2005). Report of the State Bank of Pakistan.

Stock, James, Jonathan Wright and Motohiro Yogo (2002). "A Survey of Weak Instruments and Weak Identification in Generalized Method of Moments." Journal of Business and Economic Statistics, 20, 518-29.

Summers, Robert and Alan Heston (1988). "A New Set of International Comparisons of Real Product and Price Levels Estimates for 130 Countries, 1950-85." Review of Income and Wealth, XXXIV, 1-25.

Temple, Jonathan (2002) "Openness, Inflation and the Phillips Curve: A Puzzle." Journal of Money, Credit and Banking, 34, 450-468.

Terra, Cristina (1998). "Openness and Inflation: A New Assessment." Quarterly Journal of Economics, 641-48.

Tornell, Aaron and Andres Velasco (2000). "Fixed Versus Flexible Exchange Rates: Which Provides More Fiscal Discipline?" Journal of Monetary Economics, 399-436.

Wacziarg, Romain and Karen Welch (2003). "Trade Liberalization and Growth: New Evidence." NBER working paper, no. 10152.

Winters, Alan, Neil McCulloch and Andrew McKay (2004). "Trade Liberalization and Poverty: The Evidence so Far." Journal of Economic Literature, 72-115. 


\section{Appendix A: Countries included in Table 2 regressions}

Algeria, Argentina, Australia, Austria, Barbados, Belgium, Bolivia, Burkina Faso, Burundi, Cameroon, Canada, Central African Republic, Chad, Chile, Colombia, Cost Rica, Cyprus, Democratic Republic of Congo, Dominican Republic, Denmark, Ecuador, Egypt, El Salvador, Ethiopia, Fiji, Finland, France, Gabon, Gambia, Germany, Ghana, Greece, Guatemala, Haiti, Honduras, Hong Kong, Iceland, India, Indonesia, Ireland, Israel, Italy, Ivory Coast, Jamaica, Japan, Jordan, Kenya, Korea, Lesotho Liberia, Luxembourg, Madagascar, Malawi, Malaysia, Malta, Mauritania, Mauritius, Mexico, Morocco, Niger, Nigeria, Nepal, Netherlands, New Zealand, Norway, Pakistan, Panama, Papa New Guinea, Paraguay, Peru, Philippines, Portugal, Rwanda, Senegal, Sierra Leone, Singapore, South Africa, Spain, Sri Lanka, Sudan, Surinam, Swaziland, Sweden, Switzerland, Tanzania, Thailand, Togo, Trinidad and Tobago, Turkey, Uganda, Uruguay, United Kingdom, United States, Venezuela, Zambia, Zimbabwe.

The following 12 countries drop out of the sample used in Table 3 due to data for some of the controls being unavailable for those countries: Belgium, Fiji, Iceland, Liberia, Lesotho, Luxembourg, Malta, Mauritania, Sudan, Singapore, Surinam, Swaziland.

\section{Appendix B: Data sources}

VINF, INF: International Financial Statistics, line 64

OPEN, POP and RGDP: Penn World Tables, version 6.1 (October 2002)

PRIMEXP: World Bank

$V O L$ : Calculated from $R G D P$, see above for source

TPVOL: IMF's Direction of Trade Statistics database

$B M P$ : World Bank

GROWTH: Calculated from $R G D P$, see above for source

XRATE: Reinhart and Rogoff (2004)

VMON,VTOT,GOV,FDI,CAPF LOW S,AGRI,MANU F: World Development Indicators

PRIVY: Beck, Demirguc-Kunt and Levine (1999)

$P C I$ : Henisz (2000)

CLIMVOL: Earth Institute, Columbia University 


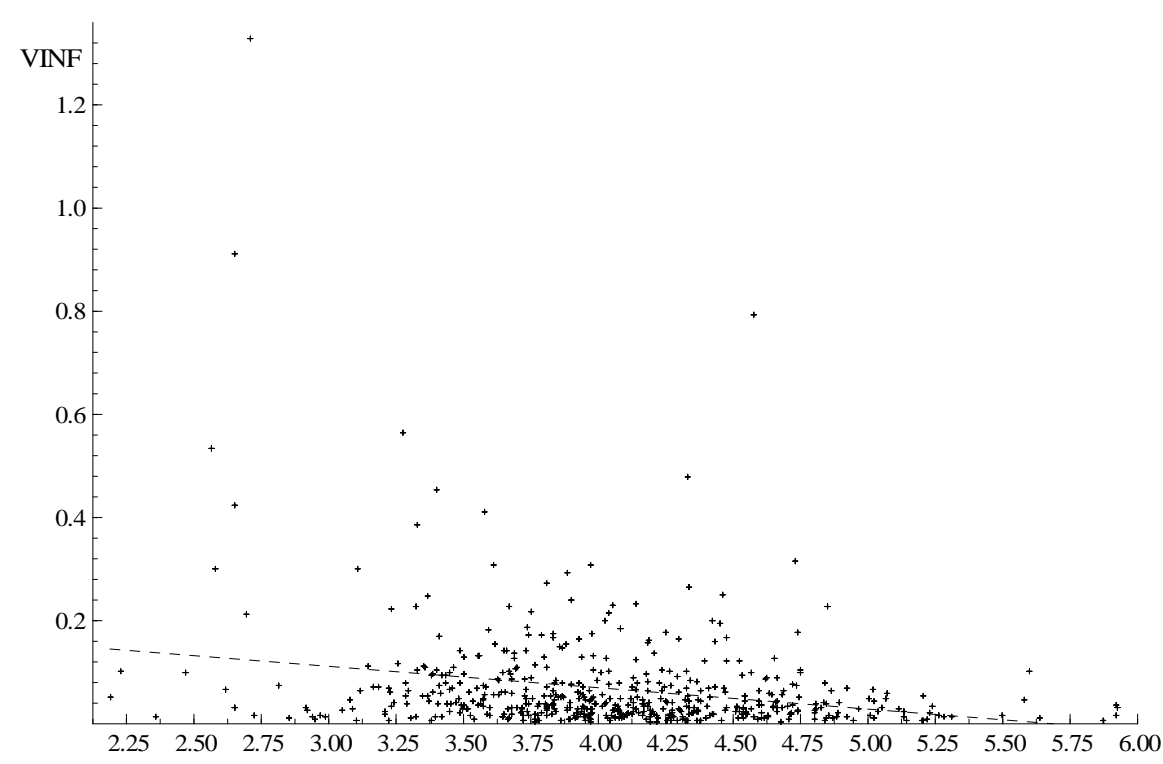

OPEN

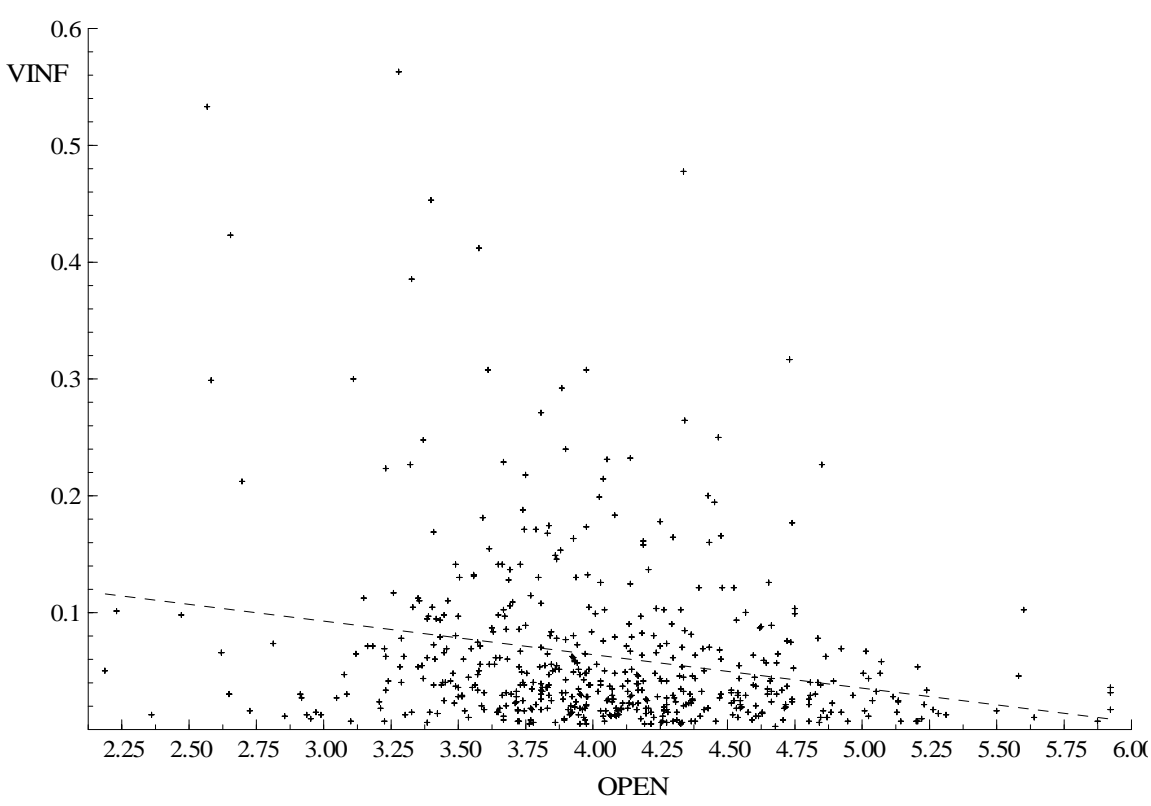

OPEN

Notes: Inflation volatility (VINF) is the log of one plus the decimal standard deviation of quarterly observations on the annual inflation rate. Openness (OPEN) is the log of exports plus imports as a percentage of GDP. The left-hand side graphs plots the 538 observations used to fit column 4 of Table 2. The right-hand side graph is the same except that the three largest readings for inflation volatility are omitted. 


\begin{tabular}{|c|c|c|c|c|c|c|c|}
\hline & $N$ & $1971-75$ & $1976-80$ & $1981-85$ & $1986-90$ & 1991-95 & $1996-00$ \\
\hline \multicolumn{8}{|l|}{ Inflation Volatility } \\
\hline All & 51 & 6.383 & 4.428 & 5.103 & 5.932 & 6.0258 & 3.737 \\
\hline Developing & 26 & 7.866 & 5.928 & 7.284 & 10.113 & 10.292 & 6.360 \\
\hline Low-income $e^{b}$ & 9 & 8.410 & 6.813 & 6.907 & 12.527 & 13.321 & 6.721 \\
\hline \multicolumn{8}{|l|}{ Primary Commodity } \\
\hline Exporters ${ }^{\mathrm{a}}$ & 5 & 6.185 & 5.688 & 5.253 & 7.968 & 8.139 & 2.744 \\
\hline Sub-Saharan Africa & 6 & 7.609 & 6.625 & 8.867 & 15.145 & 16.106 & 6.982 \\
\hline Latin America \& Caribbean & 13 & 8.170 & 6.338 & 7.456 & 11.365 & 11.621 & 8.072 \\
\hline South Asia & 3 & 8.514 & 6.292 & 4.237 & 3.270 & 2.663 & 3.991 \\
\hline Middle East \& North Africa & 5 & 6.210 & 4.372 & 3.820 & 2.985 & 2.931 & 1.929 \\
\hline East Asia \& Pacific & 6 & 7.132 & 2.894 & 5.302 & 2.626 & 1.617 & 1.439 \\
\hline W. Europe \& N. America & 18 & 4.127 & 2.532 & 2.583 & 1.302 & 1.514 & 0.750 \\
\hline \multicolumn{8}{|l|}{ Trade Openness } \\
\hline All & 51 & 60.008 & 69.389 & 69.319 & 69.230 & 74.558 & 73.497 \\
\hline Developing & 26 & 48.304 & 57.041 & 52.300 & 54.560 & 64.727 & 68.390 \\
\hline Low-income ${ }^{b}$ & 9 & 42.554 & 49.477 & 42.810 & 42.705 & 51.650 & 54.657 \\
\hline \multicolumn{8}{|l|}{ Primary Commodity } \\
\hline Exporters ${ }^{a}$ & 5 & 51.643 & 59.707 & 53.051 & 55.026 & 66.184 & 72.654 \\
\hline Sub-Saharan Africa & 6 & 50.079 & 56.049 & 47.777 & 47.755 & 57.753 & 58.737 \\
\hline Latin America \& Caribbean & 13 & 50.138 & 59.228 & 52.272 & 56.778 & 65.157 & 67.067 \\
\hline South Asia & 3 & 30.0407 & 39.376 & 38.954 & 37.294 & 44.443 & 47.382 \\
\hline Middle East \& North Africa & 5 & 66.069 & 76.911 & 77.684 & 76.970 & 83.871 & 79.457 \\
\hline East Asia \& Pacific & 6 & 82.875 & 105.662 & 109.219 & 110.306 & 118.645 & 85.140 \\
\hline W. Europe \& N. America & 18 & 65.850 & 72.149 & 78.774 & 75.194 & 74.685 & 82.523 \\
\hline
\end{tabular}

Notes:

Inflation volatility is the standard deviation of annual percentage inflation at the quarterly frequency

Regions defined on the basis of World Bank classifications.

a. Based on the World Bank classification of fuel and non-fuel primary exporters. Major exports are those that account for 50 percent or more of total exports of goods and services from one category in the period 1988-92 (non-fuel primary exports: SITC 0, 1, 2, 4 and 68; fuel exports: SITC3)

b. The low income group is a sub-set of the developing country group and is based on World Bank classifications

Trade openness is exports plus imports as a percentage of GDP 
TABLE 2: BASIC RESULTS

\begin{tabular}{|c|c|c|c|c|c|c|}
\hline & \multicolumn{6}{|c|}{ D E P E N D E N T V A R I A B L E - Inflation volatility (VINF) } \\
\hline & (1) & (2) & (3) & $(4)$ & (5) & (6) \\
\hline & OLS & $W G$ & GMM & System & System & System \\
\hline$V I N F_{t-1}$ & $\begin{array}{c}.737 \\
(4.13)\end{array}$ & $\begin{array}{c}.384 \\
(1.91)\end{array}$ & $\begin{array}{c}.530 \\
(2.36)\end{array}$ & $\begin{array}{c}.581 \\
(3.28)\end{array}$ & $\begin{array}{c}.729 \\
(2.82)\end{array}$ & $\begin{array}{c}.587 \\
(3.06)\end{array}$ \\
\hline OPEN & -.021 & -.056 & -.124 & -.086 & -.111 & -.104 \\
\hline \multirow[t]{2}{*}{ POP } & (2.58) & $(2.51)$ & (1.94) & $(2.34)$ & (1.03) & $\begin{array}{l}(2.48) \\
-.001 \\
(0.09)\end{array}$ \\
\hline & \multicolumn{6}{|c|}{ D I A G N OS TIC TESTS (P-VALUE) } \\
\hline \multirow{2}{*}{\multicolumn{7}{|c|}{$\begin{array}{l}\text { SERIAL CORR. TESTS } \\
\text { First-Order }\end{array}$}} \\
\hline & 0.632 & 0.113 & 0.017 & 0.000 & 0.001 & 0.005 \\
\hline Second-Order & 0.196 & 0.017 & 0.762 & 0.658 & 0.579 & 0.826 \\
\hline Sargan & - & - & 0.547 & 0.348 & 0.403 & 0.336 \\
\hline \multicolumn{7}{|c|}{ Difference-Sargan statistics for column (4): $\operatorname{VINF}(0.20)$ OPEN(0.76) POP(0.34) } \\
\hline \multirow[t]{4}{*}{ NT } & 538 & 538 & 442 & 538 & 538 & 512 \\
\hline & \multicolumn{6}{|c|}{ I N S T R U M E N T S } \\
\hline & \multicolumn{6}{|c|}{$\operatorname{VINF}(t-2) \operatorname{OPEN}(t-2) \quad P O P(t-2, t-3)$} \\
\hline & \multicolumn{6}{|c|}{ Instruments for level equations: $\triangle O P E N(t-1) \triangle P O P(t-2)$} \\
\hline
\end{tabular}

Notes:

Estimates are based on a sample of 96 countries, with at least 3 time observations available for each country. Period dummies are included in all specifications (but are not reported) and are also part of the instrument set. Numbers in parentheses are absolute t-statistics based on robust standard errors.

OLS denotes ordinary least squares, WG denotes within groups, GMM denotes 1-step generalised method of moments estimation of the first differenced equation and System denotes 1-step joint generalised method of moments estimation of the first differenced and levels equations.

The Sargan and Difference-Sargan tests of over-identifying restrictions are based on 2-step GMM estimates in order to correct for heteroscedasticity and are asymptotically distributed as $\chi 2(n-p)$, where $n$ is the number of moment conditions and $p$ is the number of parameters. The serial correlation tests are asymptotically distributed as $N(0,1)$ under the null of no serial correlation. 
TABLE 3: AdDITIONAL CONTROLS

\begin{tabular}{|c|c|c|c|c|c|c|c|c|c|c|}
\hline & \multicolumn{10}{|c|}{ D E P E N D E N T V A R I A B L E - Inflation volatility (VINF) } \\
\hline & (1) & (2) & (3) & $(4)$ & (5) & (6) & $(7)$ & $(8)$ & (9) & (10) \\
\hline$V I N F_{t-1}$ & $\begin{array}{c}.367 \\
(2.01)\end{array}$ & $\begin{array}{c}.020 \\
(0.33)\end{array}$ & $\begin{array}{c}.007 \\
(0.10)\end{array}$ & $\begin{array}{c}.002 \\
(0.03)\end{array}$ & $\begin{array}{l}-.002 \\
(0.03)\end{array}$ & $\begin{array}{c}.013 \\
(0.22)\end{array}$ & $\begin{array}{c}.016 \\
(0.27)\end{array}$ & $\begin{array}{c}.026 \\
(0.44)\end{array}$ & $\begin{array}{l}.023 \\
(0.43)\end{array}$ & $\begin{array}{l}.030 \\
(0.54)\end{array}$ \\
\hline OPEN & $\begin{array}{l}-.064 \\
(2.02)\end{array}$ & $\begin{array}{l}-.044 \\
(2.19)\end{array}$ & $\begin{array}{c}-.037 \\
(1.92)\end{array}$ & $\begin{array}{c}-.040 \\
(2.15)\end{array}$ & $\begin{array}{c}-.045 \\
(2.35)\end{array}$ & $\begin{array}{c}-.046 \\
(2.27)\end{array}$ & $\begin{array}{l}-.040 \\
(2.17)\end{array}$ & $\begin{array}{l}-.045 \\
(2.41)\end{array}$ & $\begin{array}{l}-.028 \\
(1.84)\end{array}$ & $\begin{array}{l}-.040 \\
(2.16)\end{array}$ \\
\hline INF & & $\begin{array}{c}.609 \\
(9.51)\end{array}$ & $\begin{array}{c}.609 \\
(9.46)\end{array}$ & $\begin{array}{c}.610 \\
(9.50)\end{array}$ & $\begin{array}{c}.589 \\
(8.43)\end{array}$ & $\begin{array}{c}.629 \\
(10.60)\end{array}$ & $\begin{array}{c}.604 \\
(9.20)\end{array}$ & $\begin{array}{c}.608 \\
(9.34)\end{array}$ & $\begin{array}{c}.579 \\
(6.89)\end{array}$ & $\begin{array}{c}.603 \\
(9.32)\end{array}$ \\
\hline RGDP & & & $\begin{array}{l}-.003 \\
(0.47)\end{array}$ & & & & & & & $\begin{array}{c}.003 \\
(0.28)\end{array}$ \\
\hline RGDP*POP & & & & $\begin{array}{l}-.004 \\
(0.67)\end{array}$ & & & & & & $\begin{array}{c}.003 \\
(0.29)\end{array}$ \\
\hline PRIMARY*OPEN & & & & & $\begin{array}{c}.007 \\
(0.97)\end{array}$ & & & & & $\begin{array}{c}.010 \\
(0.89)\end{array}$ \\
\hline$V O L$ & & & & & & $\begin{array}{c}.304 \\
(1.13)\end{array}$ & & & & $\begin{array}{c}.052 \\
(0.23)\end{array}$ \\
\hline TPVOL & & & & & & & $\begin{array}{l}2.498 \\
(2.03)\end{array}$ & & & $\begin{array}{l}1.435 \\
(1.38)\end{array}$ \\
\hline$B M P$ & & & & & & & & $\begin{array}{c}.001 \\
(0.04)\end{array}$ & & $\begin{array}{r}-.025 \\
(1.14)\end{array}$ \\
\hline \multirow[t]{2}{*}{ GROWTH } & & & & & & & & & $\begin{array}{r}-.465 \\
(1.86) \\
\end{array}$ & $\begin{array}{c}-.416 \\
(1.64) \\
\end{array}$ \\
\hline & \multicolumn{10}{|c|}{ D I A G N OS TIC TESTS (P-V A L U E ) } \\
\hline SERIAL CORR. TESTS & & & & & & & & & & \\
\hline First-Order & 0.002 & 0.001 & 0.001 & 0.001 & 0.001 & 0.001 & 0.004 & 0.001 & .003 & .004 \\
\hline Second-Order & 0.765 & 0.364 & 0.350 & 0.355 & 0.351 & 0.228 & 0.299 & 0.393 & .129 & .107 \\
\hline Sargan & 0.174 & 0.248 & 0.245 & 0.387 & 0.246 & 0.537 & 0.161 & 0.187 & .306 & .827 \\
\hline Diff-Sargan & & 0.91 & 0.52 & 0.75 & 0.66 & 0.82 & 0.20 & 0.20 & .319 & \\
\hline NT & 451 & 451 & 451 & 451 & 451 & 451 & 451 & 451 & 451 & 451 \\
\hline
\end{tabular}

See notes to Table 2. The instruments in column 1 are as in Table 2 except that in the first half of the system OPEN(t-2,t-3) is used. In columns 2-10 the additional instrument is the marginal regressor at $t-2$, except for the variables INF and GROWTH for which $t-3$ is used. Also, $\triangle I N F(t-2)$ is used to instrument the levels equations in columns that control for INF. Column 6 uses $\triangle V O L(t-2)$ as an instrument in the second half of the system. Diff-Sargan tests the validity of moment conditions based on the marginal instruments. 
TABle 4: The Role of The Exchange RAte Regime

D E P E N D E N T V A R I A B L E - Inflation volatility (VINF)

\begin{tabular}{|c|c|c|c|c|c|c|c|c|}
\hline & (1) & (2) & (3) & (4) & (5) & (6) & (7) & (8) \\
\hline & System & System & System & System & WG & WG & WG & $W G$ \\
\hline$V I N F_{t-1}$ & $\begin{array}{c}.435 \\
(2.26)\end{array}$ & $\begin{array}{c}.426 \\
(2.29)\end{array}$ & $\begin{array}{c}.089 \\
(1.58)\end{array}$ & $\begin{array}{l}-.113 \\
(0.80)\end{array}$ & $\begin{array}{c}.261 \\
(2.22)\end{array}$ & $\begin{array}{c}.080 \\
(2.07)\end{array}$ & $\begin{array}{c}.269 \\
(2.26)\end{array}$ & $\begin{array}{c}.083 \\
(2.10)\end{array}$ \\
\hline OPEN & $\begin{array}{l}-.060 \\
(2.31)\end{array}$ & $\begin{array}{l}-.058 \\
(2.30)\end{array}$ & $\begin{array}{l}-.032 \\
(1.87)\end{array}$ & $\begin{array}{l}-.042 \\
(2.03)\end{array}$ & $\begin{array}{l}-.022 \\
(2.01)\end{array}$ & $\begin{array}{l}-.035 \\
(3.37)\end{array}$ & $\begin{array}{l}-.019 \\
(1.66)\end{array}$ & $\begin{array}{l}-.034 \\
(3.22)\end{array}$ \\
\hline INF & & & $\begin{array}{c}.624 \\
(10.30)\end{array}$ & $\begin{array}{c}.350 \\
(2.02)\end{array}$ & & $\begin{array}{c}.615 \\
(11.40)\end{array}$ & & $\begin{array}{c}.613 \\
(11.50)\end{array}$ \\
\hline XRATE & $\begin{array}{c}.004 \\
(0.38)\end{array}$ & $\begin{array}{c}-.030 \\
(0.59)\end{array}$ & $\begin{array}{l}-.009 \\
(1.89)\end{array}$ & & $\begin{array}{c}.019 \\
(3.30)\end{array}$ & $\begin{array}{c}.002 \\
(0.85)\end{array}$ & $\begin{array}{c}-.013 \\
(0.54)\end{array}$ & $\begin{array}{l}-.007 \\
(0.59)\end{array}$ \\
\hline \multirow[t]{2}{*}{ XRATE squared } & & $\begin{array}{c}.008 \\
(0.70)\end{array}$ & & & & & $\begin{array}{c}.007 \\
(1.18)\end{array}$ & $\begin{array}{c}.002 \\
(0.69)\end{array}$ \\
\hline & \multicolumn{8}{|c|}{ D I A G N O S T I C TESTS (p-value) } \\
\hline \multicolumn{9}{|c|}{ SERIAL CORR. TESTS } \\
\hline First-Order & 0.004 & 0.005 & 0.002 & 0.004 & 0.065 & 0.016 & 0.065 & 0.018 \\
\hline Second-Order & 0.597 & 0.629 & 0.277 & 0.301 & 0.051 & 0.000 & 0.053 & 0.000 \\
\hline Sargan & 0.232 & 0.196 & 0.468 & 0.664 & - & - & - & - \\
\hline Diff-Sargan & 0.580 & 0.570 & - & - & - & - & - & - \\
\hline \multirow[t]{3}{*}{ NT } & 456 & 456 & 456 & 286 & 456 & 456 & 456 & 456 \\
\hline & \multicolumn{8}{|c|}{ I N S T R U M E N T S } \\
\hline & \multicolumn{8}{|c|}{$\operatorname{VINF}(t-2) \quad$ OPEN $(t-2) \quad P O P(t-2, t-3) \operatorname{INF}(t-3)$ XRATE $(t-2)$} \\
\hline
\end{tabular}

See notes to Table 2 .

Diff-Sargan tests the validity of the moment conditions based on XRATE. Columns (1) and (2) exclude the instruments for INF, since INF is not included in the explanatory variables in those regressions. Column (4) excludes the XRATE instruments because XRATE is not included in the explanatory variables in that regression. 
TABLE 5: Sub-SAMPle ANalysis

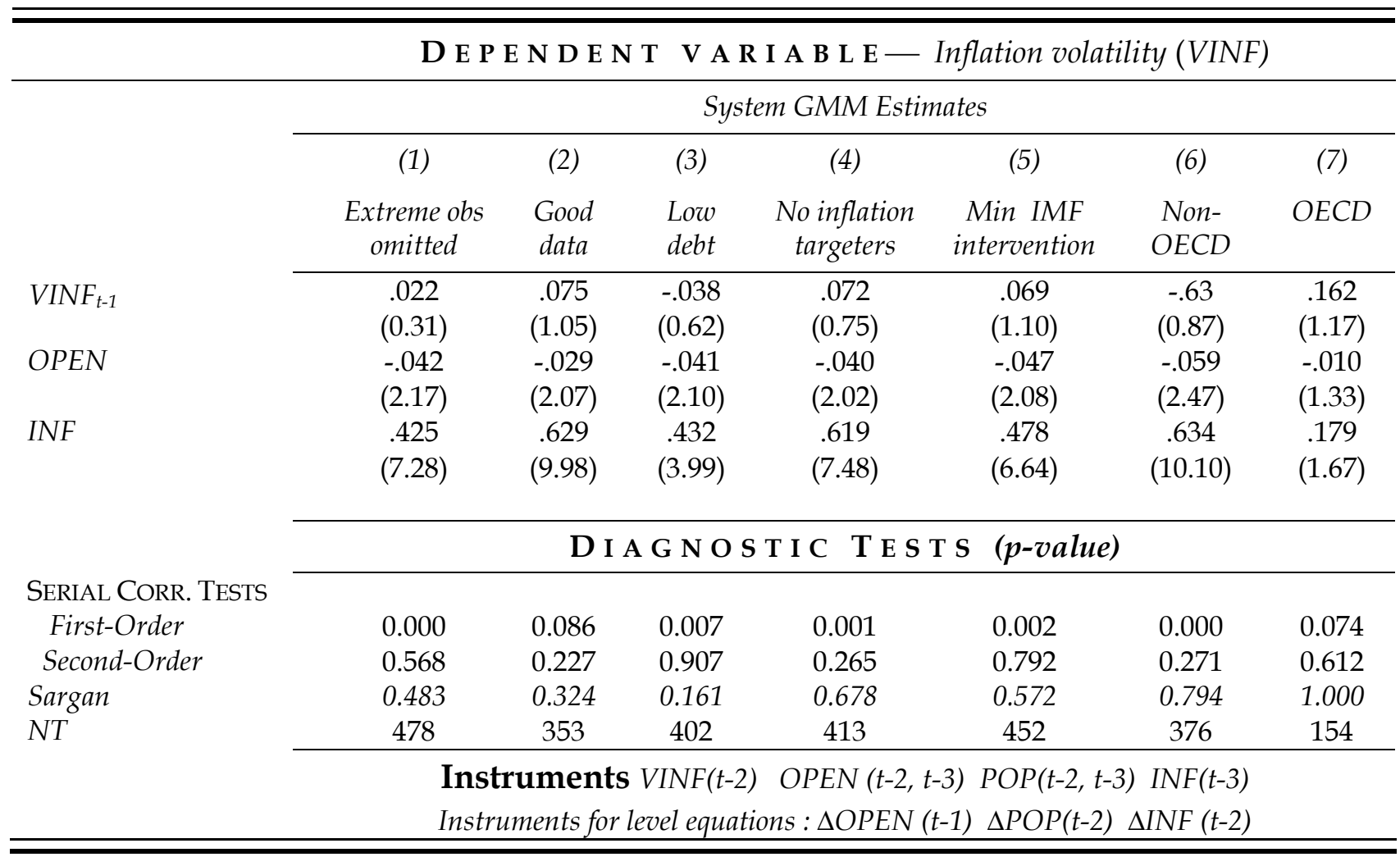

See notes to Table 2. The instrument set varies slightly. Col (2) omits OPEN(t-2) and $\triangle P O P(t-2)$. Col (6) omits $\operatorname{OPEN}(t-3)$ and $\triangle P O P(t-2)$. Col (7) omits OPEN $(t-3), P O P(t-3)$ and $\triangle O P E N(t-1)$ but includes $\triangle R G D P(t-1)$. 
Table 7: Probing Deeper for Possible Channels

\begin{tabular}{|c|c|c|c|c|c|c|c|c|}
\hline & \multicolumn{8}{|c|}{ D E P E N D E N T V A R I A B L E - Inflation volatility (VINF) } \\
\hline & \multicolumn{8}{|c|}{ System GMM Estimates } \\
\hline & (1) & (2) & (3) & (4) & (5) & (6) & (7) & (8) \\
\hline$V I N F_{t-1}$ & $\begin{array}{c}.032 \\
(0.61)\end{array}$ & $\begin{array}{l}-.016 \\
(0.36)\end{array}$ & $\begin{array}{c}.020 \\
(0.41)\end{array}$ & $\begin{array}{l}-.002 \\
(0.96)\end{array}$ & $\begin{array}{c}.014 \\
(0.26)\end{array}$ & $\begin{array}{l}.026 \\
(0.60)\end{array}$ & $\begin{array}{c}.007 \\
(0.15)\end{array}$ & $\begin{array}{l}.011 \\
(0.25)\end{array}$ \\
\hline OPEN & $\begin{array}{l}-.040 \\
(2.05)\end{array}$ & $\begin{array}{l}-.027 \\
(1.60)\end{array}$ & $\begin{array}{l}-.018 \\
(1.14)\end{array}$ & $\begin{array}{l}-.015 \\
(1.05)\end{array}$ & $\begin{array}{l}-.048 \\
(2.38)\end{array}$ & $\begin{array}{l}-.032 \\
(1.83)\end{array}$ & $\begin{array}{c}-.025 \\
(1.58)\end{array}$ & $\begin{array}{l}-.019 \\
(1.33)\end{array}$ \\
\hline INF & $\begin{array}{c}.500 \\
(8.15)\end{array}$ & $\begin{array}{c}.424 \\
(5.09)\end{array}$ & $\begin{array}{c}.491 \\
(9.51)\end{array}$ & $\begin{array}{c}.423 \\
(5.70)\end{array}$ & $\begin{array}{c}.516 \\
(8.79)\end{array}$ & $\begin{array}{c}.436 \\
(5.20)\end{array}$ & $\begin{array}{c}.500 \\
(9.65)\end{array}$ & $\begin{array}{c}.430 \\
(5.81)\end{array}$ \\
\hline$V M O N$ & & $\begin{array}{c}.304 \\
(1.96)\end{array}$ & & $\begin{array}{c}.224 \\
(1.71)\end{array}$ & & $\begin{array}{c}.290 \\
(1.92)\end{array}$ & & $\begin{array}{c}.218 \\
(1.72)\end{array}$ \\
\hline VTOT & & & $\begin{array}{c}.239 \\
(2.55)\end{array}$ & $\begin{array}{c}.193 \\
(2.45)\end{array}$ & & & $\begin{array}{c}.351 \\
(1.78)\end{array}$ & $\begin{array}{c}.188 \\
(2.42)\end{array}$ \\
\hline \multirow[t]{2}{*}{$V O L$} & & & & & $\begin{array}{c}.500 \\
(2.31)\end{array}$ & $\begin{array}{c}.196 \\
(1.14)\end{array}$ & $\begin{array}{c}.222 \\
(2.43)\end{array}$ & $\begin{array}{c}.135 \\
(0.84)\end{array}$ \\
\hline & \multicolumn{8}{|c|}{ DIAGNOSTIC TESTS } \\
\hline \multicolumn{9}{|c|}{ SERIAL CORR. TESTS } \\
\hline First-Order & 0.001 & 0.000 & 0.001 & 0.001 & 0.001 & 0.000 & 0.001 & 0.001 \\
\hline Second-Order & 0.708 & 0.562 & 0.835 & 0.677 & 0.369 & 0.493 & 0.641 & 0.626 \\
\hline Sargan & 0.546 & 0.964 & 0.694 & 0.990 & 0.739 & 0.985 & 0.856 & 0.999 \\
\hline Diff-Sargan & - & 1.00 & 0.76 & - & - & - & - & - \\
\hline NT & 344 & 344 & 344 & 344 & 344 & 344 & 344 & 344 \\
\hline & \multicolumn{8}{|c|}{ I N S T R U M E N T S } \\
\hline & \multicolumn{8}{|c|}{$\begin{array}{l}\text { VINF(t-2 t-4) OPEN(t-2) POP }(t-2, t-4) \operatorname{INF}(t-3 t-4) V M O N(t-2, t-4) V T O T(t-2) V O L(t-2) \\
\quad \text { For level equations : } \triangle O P E N(t-1) \Delta P O P(t-2) \Delta I N F(t-2) \Delta V M O N(t-1) \Delta V T O T(t-1)\end{array}$} \\
\hline
\end{tabular}

See notes to Table 2.

Instruments for mean inflation, monetary volatility, terms of trade volatility and output volatility are used only in equations in which those terms are included in the regressors. 
TABLE 8: A ClOSER LOOK AT THE INTERMEDIATE CHANNELS

\begin{tabular}{|c|c|c|c|c|c|c|}
\hline & \multicolumn{6}{|c|}{ D E P E N D E N T V A R I A B L E - VMON, VSEIGN, VTOT } \\
\hline & \multicolumn{6}{|c|}{ System GMM Estimates } \\
\hline & (1) & (2) & (3) & (4) & (5) & (6) \\
\hline OPEN & $\begin{array}{l}.067 \\
(2.02)\end{array}$ & $\begin{array}{l}.053 \\
(2.18)\end{array}$ & $\begin{array}{l}.085 \\
(2.50)\end{array}$ & $\begin{array}{c}.058 \\
(1.79)\end{array}$ & $\begin{array}{c}-134 \\
(2.82)\end{array}$ & $\begin{array}{l}-.070 \\
(1.96)\end{array}$ \\
\hline$V M O N_{t-1}$ & $\begin{array}{c}.138 \\
(1.66)\end{array}$ & $\begin{array}{l}-.058 \\
(0.89)\end{array}$ & & & & \\
\hline$V T O T_{t-1}$ & & & & & $\begin{array}{c}.004 \\
(0.04)\end{array}$ & $\begin{array}{l}-.032 \\
(0.40)\end{array}$ \\
\hline$V_{S E I G N}{ }_{t-1}$ & & & $\begin{array}{c}.006 \\
(0.04)\end{array}$ & $\begin{array}{c}.070 \\
(1.08)\end{array}$ & & \\
\hline MON & & $\begin{array}{c}.422 \\
(3.95)\end{array}$ & & & & \\
\hline TOT & & & & & & $\begin{array}{c}.454 \\
(2.93)\end{array}$ \\
\hline SEIGN & & & & $\begin{array}{c}.375 \\
(2.59)\end{array}$ & & \\
\hline$V O L$ & & $\begin{array}{c}.487 \\
(1.18)\end{array}$ & & $\begin{array}{c}.058 \\
(0.17)\end{array}$ & & $\begin{array}{c}.432 \\
(1.32)\end{array}$ \\
\hline RGDP & & $\begin{array}{c}.006 \\
(0.48)\end{array}$ & & $\begin{array}{c}.011 \\
(0.76)\end{array}$ & & $\begin{array}{c}.009 \\
(0.45)\end{array}$ \\
\hline$P O P^{*} R G D P$ & & $\begin{array}{c}-.015 \\
(1.45)\end{array}$ & & $\begin{array}{c}-.019 \\
(1.43)\end{array}$ & & $\begin{array}{l}-.029 \\
(1.48)\end{array}$ \\
\hline GROWTH & & $\begin{array}{r}-1.119 \\
(1.92)\end{array}$ & & $\begin{array}{l}-.722 \\
(2.06)\end{array}$ & & $\begin{array}{c}.143 \\
(0.34)\end{array}$ \\
\hline \multirow[t]{2}{*}{$B M P$} & & $\begin{array}{r}-.053 \\
(1.53) \\
\end{array}$ & & $\begin{array}{r}-.014 \\
(0.33) \\
\end{array}$ & & $\begin{array}{c}.069 \\
(1.71) \\
\end{array}$ \\
\hline & & & N O S 1 & T E S T & salue) & \\
\hline \multicolumn{7}{|c|}{ SERIAL CORR. TESTS } \\
\hline First-Order & 0.008 & 0.002 & 0.014 & 0.001 & 0.000 & 0.000 \\
\hline Second-Order & 0.450 & 0.324 & 0.205 & 0.163 & 0.524 & 0.409 \\
\hline Sargan & 0.735 & 0.890 & 0.095 & 0.806 & 0.203 & 0.749 \\
\hline \multirow[t]{3}{*}{ NT } & 376 & 326 & 430 & 430 & 466 & 421 \\
\hline & \multicolumn{6}{|c|}{ I N S T R U M E N T S } \\
\hline & \multicolumn{6}{|c|}{$\operatorname{VMON}(t-2, t-3) \operatorname{VTOT}(t-2, t-3)$ OPEN $(t-2, t-3) \quad P O P(t-2, t-3) \operatorname{VSEIGN}(t-2, t-3)$} \\
\hline
\end{tabular}

See notes to Table 2 .

Columns (2), (4) and (6) use the second lags of each of the extra variables included in those equations as additional instruments for the first differenced equations. Columns (5) and (6) use $\triangle P O P(t-1)$ rather than $\triangle P O P(t-2)$. 


\section{Special appendix for referees (not part of the paper submitted for publication)}

In this special appendix we first consider alternative measures of inflation volatility and openness. In column 1 of Table A1 we estimate the full sample regression using $\ln (\operatorname{sd}(\mathrm{inf}))$ as the dependent variable, where inf is a number such as 3 (in the main text the dependent variable is $\ln (1+\operatorname{sd}(\mathrm{inf} / 100))$. The sample falls to 530 because the INF term in this regression is $\ln (\operatorname{mean}(\mathrm{inf}))$, which is undefined in the 8 instances in which mean inflation is negative. The coefficient multiplying openness is much larger than in comparable specifications from the main text due to the change in the units for the dependent variable, but the statistical significance of the estimate is robust.

In column (2) we measure inflation volatility as $\operatorname{sd}(\ln (1+\mathrm{inf} / 100))$. This measure is the volatility of a $\log$ rather than the log of a volatility and is intended to address the possibility that the standard deviation is a poor measure of volatility when there are blips in the inflation rate. Applying the log transform before taking the standard deviation down-weights these outliers before they are squared and therefore reduces their effect on the dependent variable. The absolute openness coefficient is quite small, reflecting the down-weighting of extreme observations, but is also more precisely estimated and is significant at the $5 \%$ level.

In column (3) the dependent variable is that used in the main text but OPEN is measured as the log import share in GDP. This is the measure of openness used by Romer (1993). The results are slightly weaker using this measure of openness, suggesting that the size of the export sector is relevant in determining inflation volatility. Nevertheless, the effect is significant at the $5 \%$ level.

\section{Results from static regressions}

In Table A2 we reproduce the regressions featuring additional controls (columns 310 of Table 3) except that the lagged dependent variable is excluded on the grounds that it was insignificant in all columns in Table 3 that included mean inflation. The results confirm that the relationship between openness and mean inflation is robust to using static rather than dynamic GMM-SYS models (note that GMM-SYS is an efficient and consistent estimator for static as well as dynamic panel models and has often been used in the static context, see for example Beck 2002). 


\section{Results using additional controls}

We now report models incorporating additional controls. As some of the variables are observed only from the mid-1970s, or for a subset of countries, maintaining a constant sample across the columns of Table A3 would mean discarding a large amount of information in some cases and therefore we allow the sample to fluctuate. Column 1 adds the log ratio of private credit to GDP (PRIVY). This is interpreted as a proxy for financial development, which may reduce volatility through allowing agents to smooth expenditures following income shocks. Financial depth is insignificant while openness is significant at the $10 \%$ level but has a smaller coefficient than in Table 2.

Columns 2 and 3 address the role of financial openness in setting inflation volatility by controlling for the log of one plus gross foreign direct investment as a decimal fraction of GDP (FDI) and the log ratio of private capital flows to GDP (CAPFLOWS) respectively. In both cases the proxies for financial openness are insignificant. This is consistent with the potentially ambiguous effect of financial openness on volatility - recall that Aghion et al (2004) show that foreign investments can be pro-cyclical and therefore amplify volatility, rather than restrict it through compensating for the absence of well functioning domestic credit markets. In contrast, the role of trade openness remains intact.

In column 4 we control for the political constraints index (PCI) derived by Henisz (2000), which is inversely related to the ability of individual actors to bring about a change in government policy, and in column 5 we control for the log ratio of government spending to GDP (GOV). Political constraints may reduce inflation volatility through restricting discretionary policy interventions (Satyanath and Subramanian (2004) show that political constraints, and broader measures of democracy, reduce nominal macroeconomic volatility). Large governments may stabilise economic activity if state spending less taxation is counter-cyclical, see Fatas and Mihov (2001) for some supporting evidence. In both cases the role of openness in restricting inflation volatility is unaltered, while the additional controls are insignificant. Column 6 controls for the log of one plus an index of climatic volatility (CLIMVOL) defined as the root mean square of monthly precipitation anomalies, and 
calculated by the Earth Institute at Columbia University. The role of openness is robust to controlling for this measure of climatic shocks.

Finally, columns 7 and 8 control for the log share of agriculture in GDP (AGRI) and the log share of manufacturing in GDP (MANUF). A hypothesis of interest here is that state lead industrialisation programmes may drive expansion in the manufacturing sector and thereby account for reduced inflation volatility in developing countries. It is important to demonstrate that the role of openness is robust to this effect. On the other hand, it should be noted that we argued that one channel through which openness may reduce inflation volatility is that manufacturing exports increase; as this sector provides a more stable source of income than traditional export industries in developing countries, inflation volatility will fall. Hence, the estimated effect of openness when holding constant the manufacturing share must reflect channels other than that based on export structures, e.g. a change in the composition of exports or the adoption of more disciplined monetary policy. The column 8 results show that openness remains significant after controlling for the manufacturing share, indicating that the import structure and monetary stability channels are sufficient to induce a negative relationship between openness and inflation volatility. The MANUF term is negatively signed, supporting the view that expansion in high value added sectors reduces inflation volatility, though its coefficient is poorly estimated. 
Table A1: Alternative Measures of Open and Vinf

\begin{tabular}{|c|c|c|c|}
\hline \multirow{2}{*}{\multicolumn{4}{|c|}{ 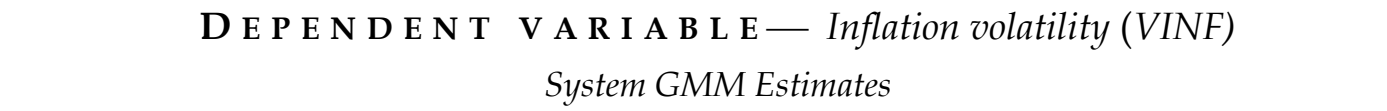 }} \\
\hline & & & \\
\hline & $(1)$ & $(2)$ & (3) \\
\hline & $\begin{array}{l}\text { Dependent variable is } \\
\ln \text { sd(100inf) }\end{array}$ & $\begin{array}{l}\text { Dependent variable } \\
\text { is sd(ln }(1+\text { inf }))\end{array}$ & $\begin{array}{l}\text { Openness is the } \\
\text { import share in GDP }\end{array}$ \\
\hline \multirow[t]{2}{*}{$V I N F_{t-1}$} & .255 & .064 & -.015 \\
\hline & (2.67) & $(0.75)$ & $(0.25)$ \\
\hline \multirow[t]{2}{*}{ OPEN } & -.559 & -.038 & -.037 \\
\hline & (2.44) & (2.42) & $(2.03)$ \\
\hline \multirow[t]{3}{*}{ INF } & .708 & .312 & .640 \\
\hline & $(6.94)$ & $(7.71)$ & $(12.20)$ \\
\hline & \multicolumn{3}{|c|}{ D I A G N OS T I C TESTS (p-value) } \\
\hline \multicolumn{4}{|c|}{ SERIAL CORR. TESTS } \\
\hline First-Order & 0.000 & 0.000 & 0.000 \\
\hline Second-Order & 0.290 & 0.387 & 0.219 \\
\hline Sargan & 0.177 & 0.360 & 0.386 \\
\hline \multirow[t]{4}{*}{ NT } & 530 & 538 & 538 \\
\hline & \multicolumn{3}{|c|}{ I N S T R U M E N T S } \\
\hline & \multicolumn{3}{|c|}{$\operatorname{VINF}(t-2) \quad O P E N(t-2, t-3) \quad P O P(t-2, t-3) \quad \operatorname{INF}(t-3)$} \\
\hline & \multicolumn{3}{|c|}{ For level equations : $\triangle O P E N(t-1) \Delta P O P(t-2) \Delta I N F(t-2)$} \\
\hline
\end{tabular}

See notes to Table 2. 
TABle A 2: Static Versions of the Models With

AdDitional CONTROLS

\begin{tabular}{|c|c|c|c|c|c|c|c|c|}
\hline & \multicolumn{3}{|c|}{ D E P E N D E N T } & \multicolumn{5}{|c|}{ A R I A B L E - Inflation volatility (VINF) } \\
\hline & \multicolumn{8}{|c|}{ System GMM Estimates } \\
\hline & (1) & (2) & (3) & (4) & (5) & (6) & (7) & (8) \\
\hline OPEN & $\begin{array}{l}-.037 \\
(1.99)\end{array}$ & $\begin{array}{l}-.040 \\
(2.26)\end{array}$ & $\begin{array}{l}-.042 \\
(2.28)\end{array}$ & $\begin{array}{l}.041 \\
(2.27)\end{array}$ & $\begin{array}{l}-.041 \\
(2.29)\end{array}$ & $\begin{array}{l}.046 \\
(2.51)\end{array}$ & $\begin{array}{c}-.029 \\
(1.85)\end{array}$ & $\begin{array}{l}.043 \\
(2.28)\end{array}$ \\
\hline INF & $\begin{array}{c}.575 \\
(6.37)\end{array}$ & $\begin{array}{c}.576 \\
(6.53)\end{array}$ & $\begin{array}{c}.545 \\
(5.99)\end{array}$ & $\begin{array}{c}.588 \\
(6.95)\end{array}$ & $\begin{array}{c}.577 \\
(6.83)\end{array}$ & $\begin{array}{c}.616 \\
(7.43)\end{array}$ & $\begin{array}{c}.572 \\
(6.89)\end{array}$ & $\begin{array}{c}.592 \\
(6.96)\end{array}$ \\
\hline RGDP & $\begin{array}{l}-.004 \\
(0.60)\end{array}$ & & & & & & & $\begin{array}{l}.003 \\
.29)\end{array}$ \\
\hline$R G D P * P O P$ & & $\begin{array}{l}-.004 \\
(0.80)\end{array}$ & & & & & & $\begin{array}{c}.003 \\
(0.28)\end{array}$ \\
\hline PRIMARY*OPEN & & & $\begin{array}{c}.009 \\
(1.35)\end{array}$ & & & & & $\begin{array}{c}.010 \\
(0.88)\end{array}$ \\
\hline$V O L$ & & & & $\begin{array}{c}.388 \\
(1.19)\end{array}$ & & & & $\begin{array}{c}.007 \\
(0.03)\end{array}$ \\
\hline TPVOL & & & & & $\begin{array}{l}2.552 \\
(2.14)\end{array}$ & & & $\begin{array}{l}1.384 \\
(1.38)\end{array}$ \\
\hline$B M P$ & & & & & & $\begin{array}{c}-.001 \\
(0.03)\end{array}$ & & $\begin{array}{c}-.025 \\
(1.05)\end{array}$ \\
\hline \multirow[t]{2}{*}{ GROWTH } & & & & & & & $\begin{array}{c}-.454 \\
(1.85) \\
\end{array}$ & $\begin{array}{r}-.363 \\
(1.63) \\
\end{array}$ \\
\hline & \multicolumn{8}{|c|}{ D I A G N OST I C TESTS (p-value) } \\
\hline SERIAL CORR. & ETS & & & & & & & \\
\hline First-Order & 0.001 & 0.001 & 0.001 & 0.001 & 0.003 & 0.001 & 0.001 & 0.002 \\
\hline Second-Order & 0.353 & 0.358 & 0.365 & 0.236 & 0.303 & 0.387 & 0.141 & 0.103 \\
\hline Sargan & 0.254 & 0.408 & 0.251 & 0.248 & 0.225 & 0.152 & 0.375 & 0.786 \\
\hline \multirow[t]{4}{*}{$N T^{\circ}$} & 451 & 451 & 451 & 451 & 451 & 451 & 451 & 451 \\
\hline & \multicolumn{8}{|c|}{ I N S T R U M E N T S } \\
\hline & \multicolumn{8}{|c|}{$\operatorname{OPEN}(t-2, t-3) \quad P O P(t-2, t-3) \quad \operatorname{INF}(t-3)$} \\
\hline & \multicolumn{8}{|c|}{ For level equations : $\triangle O P E N(t-1) \quad \triangle P O P(t-2) \quad \triangle I N F(t-2)$} \\
\hline
\end{tabular}

See notes to Table 2 .

Each column uses the second lag of the additional regressor included in that equation as an instrument for the first differenced equation, except in the case of the GROWTH variable for which the third lag is used to ensure the validity of the moment conditions. 
Table A3: Controls not Considered in the Main Text

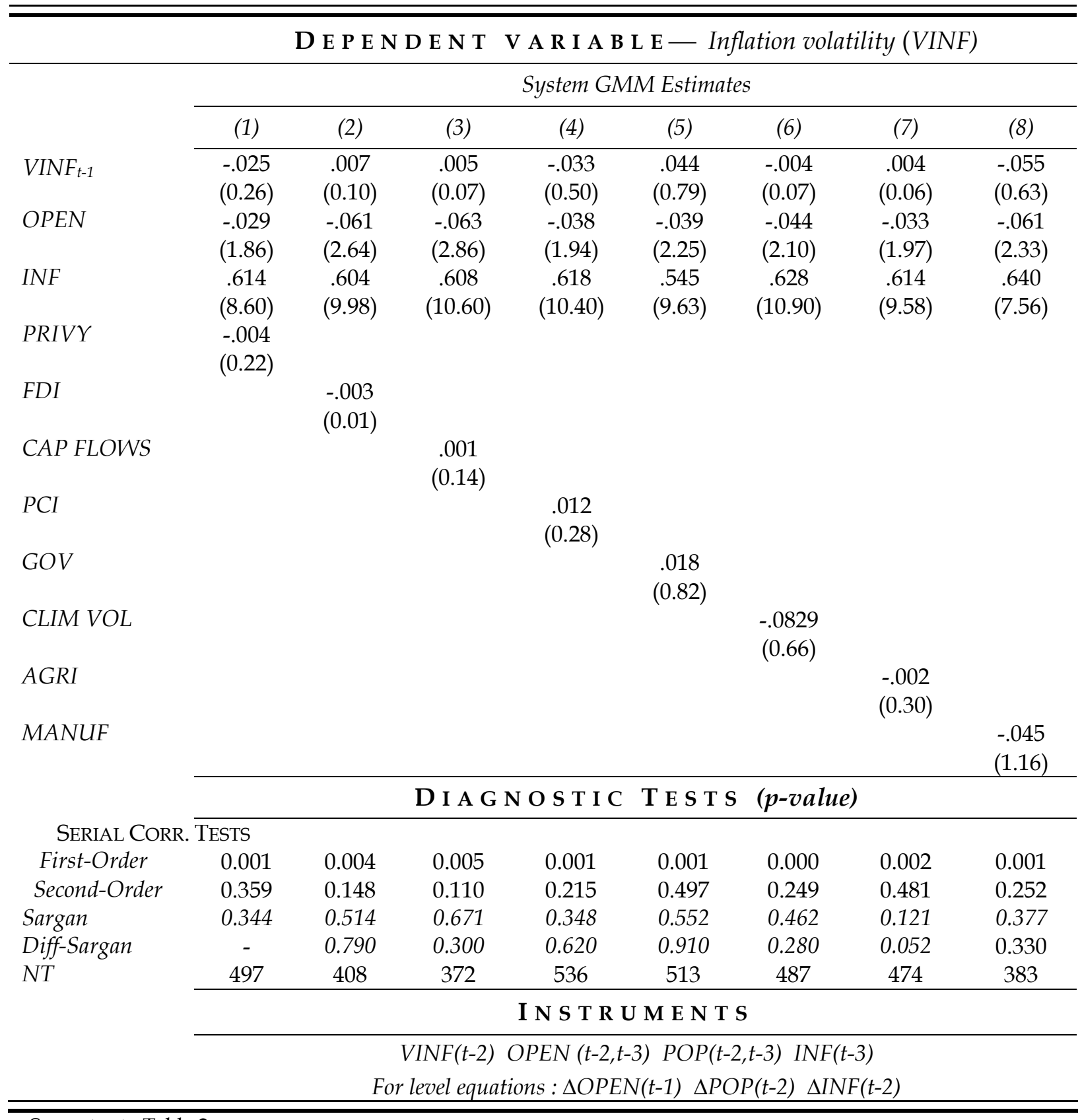

See notes to Table 2 .

Each column uses the second lag of the additional regressor included in that equation as an instrument for the first differenced equation. Column (1) adds an extra lag of each variable to the instruments used for the first differenced equations and drops $\triangle P O P(t-2)$ from the instruments for the levels equations. Column (7) uses the fourth lag of agriculture in the instruments because the second lag led to a rejection on the Difference-Sargan test. Column (8) omits $\triangle P O P(t-2)$ from the instruments. 